\title{
China-Pakistan Economic Corridor and the Impact of Coal-Based Energy Projects on Tropospheric Ozone in Pakistan
}

\author{
Ramsha Munir*, Umer Khayyam \\ Department of Development Studies, School of Social Sciences and Humanities (S3H), \\ National University of Sciences and Technology (NUST), Islamabad, Pakistan
}

Received: 12 July 2019

Accepted: 8 October 2019

\begin{abstract}
The aim of this research is to evaluate the impact of coal-fired power plants (CFPP) under CPEC on tropospheric ozone concentrations in Pakistan. The emissions from the coal plants located at Sahiwal and Port Qasim are measured using data from the 'AURA' NASA Satellite and processing using Rstudio, ARC map and Google Maps to obtain raster images. The concentration changes from the year 2010-2017 were recorded according to the buffer zones created around each coal power plant. Results showed that through the commencement of coal-fired power plants, the concentration of tropospheric ozone in those areas increased substantially from 2015 onwards. The results also showed that in winter 2017, the ozone concentration increased 7-8\% due to the operationalization of CFPP at Sahiwal and Port Qasim. This study gave evidence on the significant relationship of CFPPs on the increased formation of tropospheric ozone, hence concluding some degree of environmental degradation due to energy projects under CPEC.
\end{abstract}

Keywords: tropospheric ozone, CPEC, coal-fired power plants, Sahiwal CFPP, Port Qasim CFPP

\section{Introduction}

Economic development has long been a struggle for developing countries to acquire a robust stance against competitive markets in the world. For international and national connectivity, technological advancement, trade routes and information exchange for economic growth and development are attained through the China
Pakistan Economic Corridor (CPEC) ${ }^{1}$ under the 'One Belt One Road' initiative.

Due to the industrial revolution and upgraded lifestyles with the advancement of technology, consumption of energy has been amplified extensively [1]. Energy is an essential factor for economic growth, and all other sectors such as agriculture, transportation,

CPEC is a multi-level billion dollars mega developmental project initiated through a brotherly alliance between Pakistan and China for the formation of 'New Silk Road' from Kashgar to Gwadar and further towards Central Asia, Middle East and Africa.

*e-mail: ramsha-munir@hotmail.com 
connectivity, communication, industrialization, etc. which are dependent on electricity, hence the industrial revolution accelerated the intensity with which energy has been consumed [2, 3]. CPEC and its projects aim to change the lifestyle of Pakistani citizens through energy projects, land transportation infrastructure, and Gwadar port development, leading to expansion of trade activities, and long-term enhancement of political and economic growth $[4,5]$.

Through CPEC initiation, Pakistan's economic and social growth will transition toward a more stable and developed country, given that environmental degradation is minimized as a result of developmental projects. CPEC has been the center of the world's attention due to its strategic location, economic intensification, military significance and vast resources [6]. So far, investment by the Chinese has been the largest FDI received [7], which has provided Pakistan with the opportunity to curb its shortcomings in the energy sector that restrain its growth and loss in business due to frequent blackouts [8].

Out of $\$ 46$ billion worth of investment, $\$ 33$ billion is invested in energy projects ${ }^{2}[9,10]$. These projects comprise coal-fired power plants, solar power generation, and hydel as well as wind projects all over Pakistan [11]. The crisis of electricity deficit is expected to be alleviated through CPEC energy projects in the long run. Currently, GDP growth in Pakistan is at $2.7 \%$ in 2017 and it is expected to increase by $5.6 \%$ by 2018 [12], but with an excessive population growth of $2 \%$ annually, the demand and supply for energy are skewed toward excessive demand.

Pakistan faces inefficient electricity production, impartial power tariffs, theft, and loss during transmission, which has burdened the financial status due to excessive borrowing and foreign investment in the energy sector. In 2016, the energy deficit amounts to $6 \mathrm{GW}$, so around $6 \%$ annual growth in energy will cover the demand by 2018 , given around $24 \mathrm{GW}$ worth investments owing $8.6 \mathrm{GW}$ to CPEC, in the energy sector this is planned for the next 7-9 years [13]. CPEC has planned six power production projects with an additive capacity of $4290 \mathrm{MW}$ from local coal mines, whereas $5201 \mathrm{MW}$ of capacity will be increased by 2021 through imported coal [14]. The early harvest projects under CPEC of coal-fired power plants worth $\$ 5.8$ billion are expected to supply $7000 \mathrm{MW}$ of electricity to the national grid by 2019-2020 [15]. Pakistan has abundant coal resources, estimated at up to 185 billion tons, of which $95 \%$ is situated in the Thar coal field (Sindh), so it is deemed beneficial to invest in coal-fired power plants (CFPP) under CPEC in order to cater to demand of energy nationally [16]. Though only 3.5 million coal reserves were used domestically due to lignite coal high moisture content, clean coal technology is used

Energy projects such as early harvest projects, aim to cut energy shortfall by 2018 by 10400 MW. by Shanghai Corporation in CPEC energy projects for cleaner production and low environmental impacts and lower GHG emissions such as $\mathrm{CO}_{2}, \mathrm{CO}, \mathrm{NOx}, \mathrm{SO}_{2}$, $\mathrm{SMP}, \mathrm{O}_{3}$, etc.

Energy production, distribution, and consumption have been reckoned a foremost contributor to air pollution at local, regional and global levels. Coal is abundant in developing countries and is deemed as an affordable, safe and reliable energy source to build and industrialize economies. Even though coal demonstrates an exceptional capability to meet $50 \%$ of global energy demand [17], still the emissions of $\mathrm{CO}_{2}, \mathrm{SO}_{2}, \mathrm{NOx}$ etc. from coal-fired power plants poses an undeniable threat toward the environment and international climate change. Coal-based energy plants impact climate and air quality via emissions of $\mathrm{CO}_{2}$ (long-lived), Ozone and aerosol precursors (short-lived), $\mathrm{NOx}\left(\mathrm{NO}, \mathrm{NO}_{2}\right), \mathrm{SO}_{2}$, mercury and solid wastes, of which tropospheric ozone and particulates have adverse effects on human health, whereas ozone and sulphur compounds have damaging capabilities for natural ecosystem and biodiversity [18].

Nitrogen oxides play an important role in the formation of secondary pollutants, tropospheric ozone through photochemical reactions, also found in the form of smog in the atmosphere. NOx is a major pollutant that accounts for almost $90 \%$ of total NOx in coal-fired flu gas, resulting in the formation of photochemical smog and acid rain, with the reaction to poly aromatic hydrocarbons (PAHSA) [19]. As coal plant emissions have the potential to emit large amounts of NOx, the probability of ozone formation as a result of direct NOx emissions is high. Therefore, the energy development projects in developing countries dependent on coal implicate the excessive atmospheric emissions of NOx with increased levels of tropospheric $\mathrm{O}_{3}$, ultimately degrading the environment.

As the baseline for CFPP emissions and Tropospheric ozone formation has been established, the international treaties and conventions for its mitigation and reduction are put forward globally. ${ }^{3}$ At the global level, $\mathrm{O}_{3}$ measurements have seen a significant rise over East Asia, China, South Korea, and Japan, but due to a lack of ground-based stations in East Asia, spatial distribution and seasonal variation through satellite data is usually the effective way to find changing trends in recent years [24]. According to WHO (2006), EU ambient air directive 2010, UK, Gothenburg Protocol

In 1952, Haagen Smith first put forward the concept of tropospheric ozone in atmosphere based on California due to smog incident in Los Angeles [20]. At the national and regional level, standard guidelines were issued for ozone emissions in 1960s and 1970s by North America, European Union (EU) and Japan, but still, lack international policy initiative at that time [21]. These initiatives were taken when $\mathrm{O}_{3}$ doubled in Europe in 1950s till the 1990s but later decreased in 2000s [22], whereas in Pacific Ocean cost of the USA in spring and Japan reported strong increase for Mount Hoppo during spring [23]. 
and UNECE, internationally accepted standards were deemed at $50 \mathrm{ppb}$ at 8-hour daily mean and 60-65 ppb by EU as the critical level for human health, whereas the EU threshold for $\mathrm{O}_{3}$ is $90 \mathrm{ppb}$ per hour with an alert threshold of $120 \mathrm{ppb}$ for atmosphere [25, 26]. However, due to $\mathrm{O}_{3}$ characteristics of short-lived climate gas with the capability of intercontinental ozone transport, its policy guidance models are relatively new and not effective, yet as global models for ozone they are hampered due to a lack of observations [27]. Thus, environmental governance is imperative for implementing laws, policies and monitoring the tropospheric ozone concentrations and other GHGs according to standard levels in order to promote green sustainable development and decrease the vulnerability of communities toward climate change.

The impact of ozone on human health, crops and vegetation [28] is the result of increased concentrations in the environment as it is the strongest oxidant, and even short-term exposure to excessive tropospheric ozone levels can reduce lung function, cardiorespiratory disease and mortality, abnormality in the central nervous system and reduced productivity/developmental effects [29, 30]. Apart from internal damage, it also causes skin diseases and irritation in eyes if exposed regularly [31, 32]. Also, it has been hypothesized that long-term exposure can result in skin aging as similar to other air pollutants and results show a positive association of tropospheric ozone exposure to increased wrinkles due to chronic ultraviolet radiation, NOX and particlate matter [33].

\section{Problem Statement}

As the need for energy and coal-fired power plants under CPEC is discussed and concern about environmental degradation is highlighted, the research gap remains to evaluate the concrete evidence pertaining to the assumption of expected impacts on the environment due to CPEC coal power projects. Since the major sources of NOx are coal-power plants, changes in tropospheric ozone due to changes in the concentration of NOx are expected. Thus, this study aims to find the changes in the concentration of tropospheric ozone due to the commencement of coal-fired power plants under CPEC.

Since 2015, as CPEC projects were inaugurated, the construction of CFPP was categorized as early harvest projects to be completed by 2020, so the proactive research on expected near future impact on the environment needs to be analysed. This research will give concrete evidence regarding changes in the concentration of tropospheric ozone as a result of coal plant emissions. Based on this study, the debate on the detrimental effects could be answered to an extent that whether CFPP is a bad development decision or a good one. The unexplored area of research and attempt to find some evidence remains essential for future policy mitigation strategies.
Hypothesis

H0: There is no relationship between coal-fired power plants of CPEC on tropospheric ozone concentrations.

H1: There is a significant relationship between coalfired power plants of CPEC on tropospheric ozone concentrations.

\section{Research Questions}

Does the commencement of CPEC's coal-fired power plants have a significant impact on concentrations of tropospheric ozone in Pakistan?

1. What are the effects of coal-fired power plants on the environment of Pakistan?

2. Are coal-fired power plants under CPEC environmentally friendly initiatives?

3. What are the $\mathrm{O}_{3}$ levels in locations of coal-fired power plants before and after the commencement of CPEC energy projects?

\section{Literature Review}

\section{Formation of Tropospheric Ozone and Its Precursors}

According to OECD (2012), there will be an increased level of premature deaths in OECD countries due to tropospheric ozone, given that by 2050 the air pollution abating policies are not implemented [34]. Ozone is not directly emitted into the atmosphere but is basically a by-product through oxidation reaction and termed as a short-lived air pollutant that participates in climate change. ${ }^{4}$

It has long been considered that tropospheric ozone formation was major because of ozone transport from overlying layers under the influence of radioactive flux, but later in the 1960s the photochemical reaction of precursor gases that result in tropospheric ozone was deemed a major contributor [36, 37]. The ozone chemistry with respect to ozone modulation indicates two mechanisms that result in tropospheric ozone formation as a result of the stratosphere. One is from the total ozone-caused modulation of the ultraviolet radioactive flux that enters the troposphere and results in photochemical reaction, and the other is the direct transport of stratospheric ozone that generates the same process of ozone formation through triggering photolysis in the troposphere. Therefore, control via

\footnotetext{
Tropospheric Ozone is considered as $3^{\text {rd }}$ largest GHG in changing climate with radioactive forcing (RF) of $0.4 \pm 0.2 \mathrm{~W} \mathrm{~m}^{-2}$, that is about $14 \%$ of the present total $\mathrm{RF}$ and equal to $24 \%$ of $\mathrm{CO}$, with concerns of its concentration increase on factors such as Stratosphere-troposphere exchange, changes in trace gases i.e. $\mathrm{CH}_{4}$, VOCs, Lightening NOx and soil NOx, CO, aerosols and as a result of vehicular emissions, coal-burning and wildfires [35].
} 
ultraviolet flux determines the amplitude modulation and transport from stratosphere causes to temporal modulation [38].

The first mechanism of UVB radiation with respect to total ozone (TO) variation has a noticeable relationship on long timescales and instability in short-term scales, and increases ${ }^{5}$ (decrease of $\mathrm{TO}$ is accompanied by growth of ground-level ozone, i.e., NOC) [39]. The second mechanism essentially focuses on the transport of ozone ${ }^{6}$ from the stratosphere to troposphere in a Brewer-Dobson cell that descends vertically in ordered air motions with a velocity of $0.1 \mathrm{~cm} / \mathrm{s}$ [41]. The chemistry of tropospheric ozone is mostly determined through the photolysis of ozone with radioactive influx of UVB with wavelengths shorter than 340nm, resulting in the formation of $\mathrm{O}\left({ }^{1} \mathrm{D}\right)$ atoms ${ }^{7}$ that are able to dissociate $\mathrm{O}_{3}$ into $\mathrm{O}_{2}$ and electronically excited $\mathrm{O}(1 \mathrm{D})$ atoms react with water vapor, producing $\mathrm{OH}$ radicals [45]. Ozone is produced through the chemical reaction of NOx, CO and VOCs in the presence of sunlight, winds, temperature and humidity [46, 47], which are emitted through anthropogenic activities such as power plants, transportation vehicles, heating systems, crop burning and natural emissions [48-54]. Ozone is altered and transported through regional and inter-continental boundaries based on atmospheric diffusion that results in seasonal transport patterns and climatic variability, hence increasing concentrations in neighboring regions from source emissions points $[55,56]$. As almost $10 \%$ of the atmospheric layer consists of tropospheric ozone and almost $90 \%$ of ozone is in the stratosphere, ozone in the boundary layer due to diffusion transports into

5 Due to variations on Total Ozone (TO) results in variations in UVB influx in troposphere where photolysis results in formation of Ozone [40]. Hence though this process of influx of UVB influx changes the magnitude and spectrum with maximum shift of 310-330 $\mathrm{nm}$ which decreases photolysis rate (usually happens at 305-307 nm), confirming the mechanism of stratospheric control on the photochemical activity of ozone concentration in troposphere.

6 The transportation of ozone is caused by tropopause 'breaking' and folding in the jet stream zone which is surrounded by spiral circulation with descending side transporting ozone and ascending side transports water vapour, aerosols and trace gases hence keeping balance of momentum and thermobaric gradients of jet stream [42]. The velocity of ascending motion is Brewer-Dobson circulation system is a few tenths of $\mathrm{cm} / \mathrm{s}$ pertaining to considerable effect on timescales comparable to time intervals required for the air to descend from ozone pause altitude, which is close to tropopause level in matter of days and weeks measured by average monthly TOR levels through NASA Website $[43,44]$.

1) $\mathrm{O}_{3}+\mathrm{hn}<\mathrm{O}(1 \mathrm{D})+\mathrm{O}_{2}(1<340 \mathrm{~nm})$.

While most of the excited $\mathrm{O}$ atoms are collisionally deactivated to ground state $\mathrm{O}$ atoms which again form $\mathrm{O}_{3}$ via

2) $\mathrm{O}+\mathrm{O}_{2}+\mathrm{M}<\mathrm{O}_{3}+\mathrm{M}$,

the remaining $\mathrm{O}(1 \mathrm{D})$ atoms have enough energy to react with water vapour to produce $\mathrm{OH}$ radicals

3) $\mathrm{O}(1 \mathrm{D})+\mathrm{H}_{2} \mathrm{O}<2 \mathrm{OH}$ the free atmosphere with a longevity of several weeks, and it absorbs earth radiation that results in global warming $[57,58]$.

The prevailing factors that contribute to the changes in tropospheric ozone are proximity to point sources of $\mathrm{O}_{3}$ precursors, geographical location and weather conditions, depending on photochemical reactions and physical reactions; the transfer of ozone molecules from upwind sources (i.e., transport of $\mathrm{O}_{3}$ from stratosphere to troposphere, which was deemed the only way of ozone at ground level) [59]. Another factor that contributes to changes in tropospheric ozone is the changes in pressure due to altitude. High-pressure systems normally have high temperatures with slow winds, $\mathrm{TO}_{3}$ concentration increases at lower altitudes and vice versa for high altitudes and mountainous areas [60].

Typically, photochemical reaction takes up to a few seconds to ten minutes, where $\mathrm{O}_{3}$ production depends on the reaction between $\mathrm{NOx}, \mathrm{OH}$ radicals, $\mathrm{CO}$, hydrocarbons $\left(\mathrm{CH}_{4}\right.$, i.e., long-lived), water vapors and loss regimes from stratosphere boundary layer that could be a more than expected source of $\mathrm{O}_{3}$, henceforth ozone formation requires $\mathrm{CO}$ and hydrocarbon oxidation with NOx (shown in the figure below), whereas its destruction requires water vapors and hydrogen peroxy and hydroxyl radicals $\left(\mathrm{HOx}=\mathrm{HO}_{2}+\mathrm{OH}\right)$ [61] According to research findings, tropospheric ozone concentration increases with a rise in temperature and maximum intensity of radiation in clear days, whereas most day-to-day variation occurs in spring and summer (March-August) as compared to winter [62]. Ozone's lifespan is 23 days and its photochemical reaction needs VOCs and NOx to oxidize in the presence of UV light, high temperature, and low wind, and travels with the wind too long distances [63]. Due to the absorption of sunlight, tropospheric ozone directly influences the increase in surface temperature and global warming [64]. Urbanization, rules and regulatory policies and government initiatives have lowered emissions of ozone precursors, as the National Emission Inventory (NEI) of the U.S. EPA suggests that there was almost a $45 \%$ decline in NOx and a $16 \%$ decrease in VOCs from 2000-2014 [65]. A study conducted in China in 2012 indicated that direct pollutants emitted from coal combustion contributed $51 \%, 66 \%$ and $52 \%$ to PM2.5, $\mathrm{SO}_{2}$, and $\mathrm{NO}_{2}$, respectively, which was higher than the environmental capacity [66].

\section{Impact on Tropospheric Ozone due to Coal-Fired Power Plants}

Moussiopoulos (1990) first tried to find the relationship between power plant emissions with tropospheric ozone through the multi-box model and found that as the emissions are reduced, the ozone levels are lowered, given primarily to the reduction in the concentration of NOx [67]. There was an increase in NOx by $60-70 \%$ in the troposphere and ground-level ozone levels from 1990-1995 in Africa, Southeast Asia, 
and China due to coal power plants, the transport sector, and fossil fuel consumption emissions [68]. The coaldominant energy structures in Shandong were found to be largest emitters of air pollution, generating severe and multifaceted problems of atmosphere in the form of smog $\left(\mathrm{O}_{3}\right.$ concentration), haze and acid rain [69].

According to the USCUSA (2017), in 2014 US coal power plants emitted 1.5 million tons of $\mathrm{NOx}$, 22124 tons of VOCs and $10 \%$ of $\mathrm{CH} 4$ from coal mining practices [70]. NOx is a major ozone producer through coal power plants, with a 10-times emissions increase from 1 coal power plant unit $(\mathrm{GW})$, i.e., $0.794 \times 10^{\wedge} 15$ molecules $/ \mathrm{cm}^{2}$ in India from $2005-2007$ [71]. The annual changes in NOx in China using the GEOS-Chem model indicated that from 2005-2007, an $82 \%$ correlation was found between NOx and CFPPs locations with a concentration of $8.11 \mathrm{Tg}$ and $9.58 \mathrm{Tg}$, with a $3.8-17.2 \%$ increase in summer average OMI from six selected sites [72]. A study conducted in Pakistan on spatio-temporal variability of monthly averaged Vertical Tropospheric Columns (VTCs) of $\mathrm{NO}_{2}$ using OMI from December 2004 to November 2008 showed an increasing trend of $3.29 \%$ per year with $1.102+0.08 \times 10^{\wedge} 15$ molecules $/ \mathrm{cm}^{2}$ pertaining to the changes in air mass trajectories of its concentration on 4 hotspot regions (Rawalpindi/Islamabad, Lahore, D. I. Khan and Karachi) based on wind for its long-distance transportation [73].

In order to find a relationship between coal-fired power plants and tropospheric ozone concentrations, a study from Brazil on the CIT photochemical model using the regional atmospheric modeling system (RAMS) for winters and summers found the significant relationship of $\mathrm{TO}_{3}$ and CFPPs in summers due to high temperatures and low-intensity winds [74]. Ozone productive efficiency (OPE is derived from the fluxes of $\mathrm{O}_{3}, \mathrm{NOx}$ and $\mathrm{SO}_{2}$ concentrations) per NOx due to emissions from coal power plants found to have a strong correlation through measurement from aircraft using 2 dimensional Lagrangian for $1 \mathrm{Km}$ horizontal resolution and 3-D regional model from source points 18 hours downwind [75]. Ground-level ozone (GLO) was found in the range 6.4-24.8 with a standard deviation of $14.9 \mathrm{ppb}$, at times of high radiation from the sun during winters with the correlation of $r=0.55$ in Chandrapur from 2005-2006 due to coal usage at the source of emissions and high temperatures giving favourable conditions for ozone production [76].

China tried to evaluate the ozone formation potential (OFP) as VOCs are emitted from coal-based thermal power plants from spring and autumn of 2014, and found coal-power plants and transportation as major emitters of VOC at $29.98 \%$ and $21.25 \%$ respectively, which are higher in autumn as compared to spring due to wind speed and direction, i.e., high winds lead to low OFP values with $73.73 \%$ production of OFPs due to 10 common VOCs at coal power plant sites [77]. Coal power plants in India do have a considerable impact on the ozone formation from 2001-2010 and
2020-2021, with an exceptional increase of $150 \mu \mathrm{mb}$ over 2 coal power plant sites and overall the same $\mathrm{O}_{3}$ in other regions throughout the year [78].

For determining the methodology for measuring tropospheric ozone, the study conducted by OLTMANSA et al. (2006) analysed the climatology of ozone through satellite AURA through an ozone monitoring instrument (OMI) and microwave limb sounder (MLS). The time period of the study conducted by OLTMANSA et al. (2006) was from October 2004 to December 2010 [79]. The results were spatially and temporally distributed and showed large variability in the Atlantic and Asian regions in summer. The OMI and MLS are 2 out of 4 instruments that are installed on the AURA satellite that was first launched in July 2004 at polar orbit, $705 \mathrm{~km}$ altitude and 98.2 inclination. OMI is nadir- a scanner that is using 350-500 nm UV light channels with a resolution of $13 \mathrm{~km}$ x $24 \mathrm{~km}$. OMI can also measure $\mathrm{NOx}, \mathrm{SO}_{2}$ $\mathrm{HCHO}$, aerosols, and centroid cloud pressure apart from ozone, whereas MLS is a thermal-emission microwave limb sounder that takes vertical profiles of mesospheric, tropospheric, stratospheric, temperature, ozone, $\mathrm{CO}$ and $\mathrm{H}_{2} \mathrm{O}$ measurements after 7 minutes; OMI does readings for the same location at an ascending orbital track. All measurements are in Dobson Units $(1 \mathrm{DU}=1 / 0.65$ parts per billion) [80].

For long-term determination of ground-level ozone, the studies are hampered by lack of observational satellite data for more than 15 years, an inability to cover regional areas frequently and few sites that monitor air quality, the inability to check ozone behavior in background air at 500-1000 km scale, limited studies on the measurement of ground-level ozone, and a lack of determining changes at geographical and broader levels [81].

\section{Coal-Fired Power Plant's Environmentally Friendly Technology}

To cater the concerns of environmentalists upon the GHG emissions from CPEC CFPPs, the deployment of innovative and environmentally friendly technology such as 'supercritical emissions-reducing technology,' i.e., extensive electricity generation along with protective measures, is used [82]. Waste from direct coal combustion in processes of coal gasification though 3 types of coal (i.e., two hard coals and lignite) has a diverse impact on the environment, checked through leaching and radionuclide content in Polish power plants based on concentrations of its ash contents. Results indicate that the type of coal used in power plants has a significant influence on ash content and the type of thermal processes used [83].

The introduction of useful technologies has already been proven to reduce emissions from coal power plants and other industries, such as baghouse filters or electrostatic precipitators (ESP) with removal efficiencies of up to $99.9 \%$ or low NOx burner 
technology (LNBT), with an efficiency of $40-60 \%$ [84]. Carbon capture and storage (CCS) is the recent technology considered an innovation in technology that can reduce GHG emissions by $50-80 \%$ by 2050 [85]. In China, in order to address the excessive $\mathrm{CO}_{2}$ emissions, environmental protection equipment (i.e., for dedusting, desulfurization and denitration) have been installed in Chinese coal-fired power plants that have decreased the emissions as well as the consumption of water up to $70 \%$ in recent years [86].

Eight coal-fired power plants in China were revealed to have a reduction in NOx by $78-94 \%$ due to the installation of air pollution control devices (APCDs) and selective catalytic reduction (SCR) in checking the combustion efficiencies of anthracite, bitumen, and lignite, of which anthracite had more NOx emissions capacity [87]. Coal intensifies the ecological problems during the combustion process through waste products, which are reduced through desulphurization and denitration technologies such as a combination of SNCR and SCR technologies in their modified form, which improves its efficiency and removes shortcomings previously observed in separate processes. Other technologies like wet, dry and semi-dry desulfurization, activated carbon absorption, electron beam radiation, corona, wet desulphurization denitrition technology as well as flue gas desulfurization (wet-FGD) for $\mathrm{SO}_{2}$ reduction and selective catalytic reduction (SCR) for NOx reduction are the most widely used globally nowadays $[88,89]$.

As per government officials and Chinese construction companies, CPEC CFPPs have installed flue gas desulfurization, seawater desalination, and high-efficiency electrostatic precipitators to ensure that emissions remain within the limits of national environmental quality standards and help to preserve the freshwater marine ecosystem and protect projects from damage. Given that, these claims are met in the construction phase of coal power plants, the emissions can be expected to be lower than usual, so through this study, we estimated whether the emissions are increasing extensively or not, given that new technology is used.

\section{Materials and Methods}

Our research took data from the NASA Aura satellite, which used MLS and OMI instruments (20102017) as used by Zeimke (2011), which confirms the possibility of NASA data for further research purposes [90]. The years were divided into summers and winters based on temperature intensity per month [74]. The rationale for dividing winters and summers was due to day-to-day variations occurring in spring and summer from March to August as compared to winter, when the Tropospheric ozone concentration increase with the rise in temperature and maximum intensity of radiation on clear days [62]. Also, 6 months with a temperature greater than $22^{\circ} \mathrm{C}$ are included in summers and less than that are assigned for winters as shown by World
Bank data (2018). This strategy was used to handle a large data set and gain better results. The following steps explain the methodology used in this paper.

Raw data for 7 years was provided in both Dobson units and parts per billion (ppb). This research is based on Dobson units as they depict better results than ppb in showing prominent variations in changes in tropospheric ozone concentrations: $1 \mathrm{ppb}$ of tropospheric $\mathrm{O}_{3}=0.65$ Dobson Unit (DU) ${ }^{8}$ [91].

According to WHO, EU and UK tropospheric ozone threshold level, $50 \mathrm{ppb}$ is the maximum $\mathrm{O}_{3}$ allowed in the atmosphere, hence if $50 \mathrm{ppb}$ is converted in DU, then Dobson units should not exceed 32.5 DU 9

This shows that, per location, tropospheric ozone concentration should not exceed 32.5 DU according to WHO, European Union, United Kingdom standards [25]. No conversion from ppbv to DU was done in the study. In reality, the NASA website provides data in both DU and ppbv, and in this study only DU data was used. The above-given conversion method is only to understand the difference between ppbv and DU, as mostly ppbv studies and standard level of tropospheric ozone are given in ppbv.

\section{Processing of Raw Data}

In the processing of data, required editing of the data by deleting the extra information and using Editing Notepad++ Forming Excel file with .csv format to be used in programming, so we can get data in a simpler form in Excel for latitude and longitude. We used Rstudio software to make Excel files from edited notepad ++ . Programming model ${ }^{10}$ was used to procure processed data.

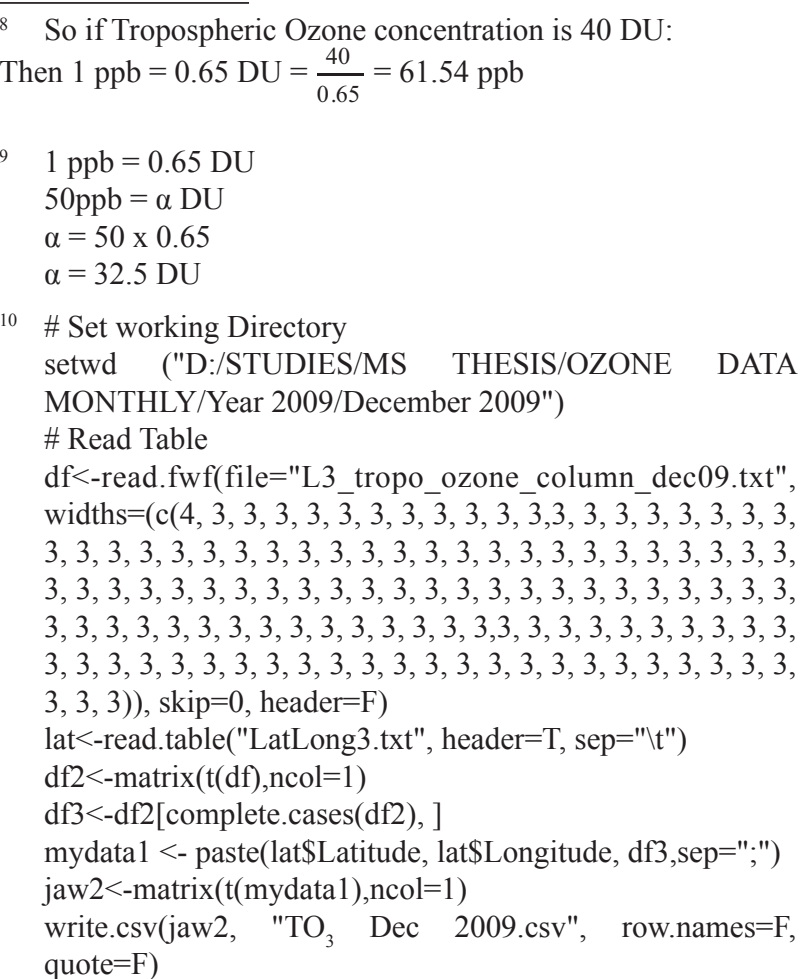




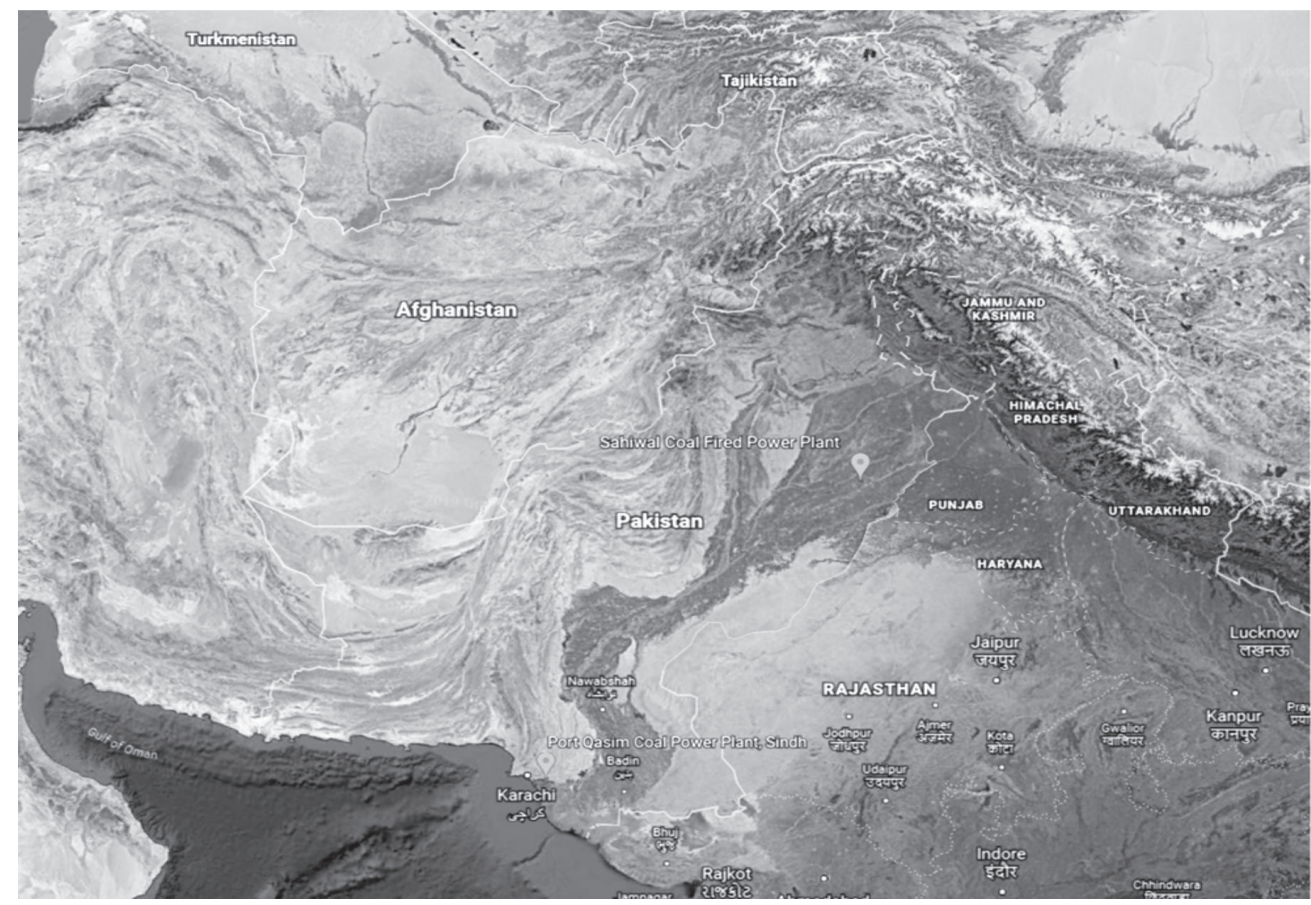

Fig. 2. Google Earth with locations for coal-fired power plants.

The obtained latitude and longitude column with a concentration of Tropospheric ozone from the programming represented in DU x10 as indicated on the website. To get the $\mathrm{O}_{3}$ in DU, we divide it by 10 to get tropospheric ozone concentrations in DU. Later, monthly data is aggregated into bi-annual categories based on seasonal and temperature changes. The months from April to September were categorized as the summer data set, and monthly data from October to March was aggregated in the winter dataset file by taking an average of six months for each year. Through this classification of winters and summers, an excel.csv file now includes the data ready for GIS mapping.

\section{GIS Mapping}

For this part of the methodology, ArcMap 10.5 software was used to obtain raster images through several instruments used to interpolate the data from latitude and longitude points to map form. The process of converting excels numerical data results in raster images showing tropospheric ozone concentration in Pakistan. It requires inserting a shapefile for Pakistan into ArcMap and using an inverse distance weighted (IDW) ${ }^{11}$ tool (Spatial Analyst) and extract by mask (Spatial analyst) instruments to get raster maps. For the tropospheric ozone data, due to its lifespan phenomenon and its unchanging and uniform distribution, it is unchanged due to source as it is a secondary pollutant

11 IDW basically, is an exact interpolator for any unpredicted location by which maximum and minimum variation of the surface data is used to capture and predict neighboring areas. and remains in the atmosphere for 23 days, making IDW most reliable and valid tool for interpolating data [64]. Data is extracted by a mask that extracts cells of the raster that correspond to the areas defined by a mask. Through this, we get the final raster image that shows the tropospheric concentrations in Pakistan.

\section{Locating CFPP Locations through Google Earth and Forming Buffer Zones}

For identifying two coal-fired power plants on the Pakistan map, coordinates of longitude and latitude are used to pinpoint the locations in order to make shapefiles and further analysis. The Sahiwal CFPP is located at $30^{\circ} 42^{\prime} 48.37^{\prime \prime} \mathrm{N} 73^{\circ} 14^{\prime} 22.04^{\prime \prime} \mathrm{E}$ and Port Qasim CFPP is situated at coordinates $24^{\circ} 47^{\prime} 7.44^{\prime \prime} \mathrm{N} 67^{\circ} 22^{\prime} 10.20^{\prime \prime} \mathrm{E}$ as shown in Figs 2-3 through Google maps.

To make the buffer zones around CFPPs, shapefiles were made using conversion tools for transforming k.ml into layer data. Evaluating the changes in the concentration of ozone through distance from point source at 10,20 and 30 miles is done through a buffer analysis tool through which buffer zones are created around each plant. Previously created shapefiles for north, south, east and west points on these buffered lines were made, and through these buffer zone points the concentration for ozone at each point is extracted from the attribute table for further analysis. This process is done for all years from 2010-2017 and values are extracted in excel. The percentage change from source point to 30 miles was calculated to obtain results. Fig. 4 indicates the buffer zones and buffer points for the summer and December 2017 raster image. 
a)

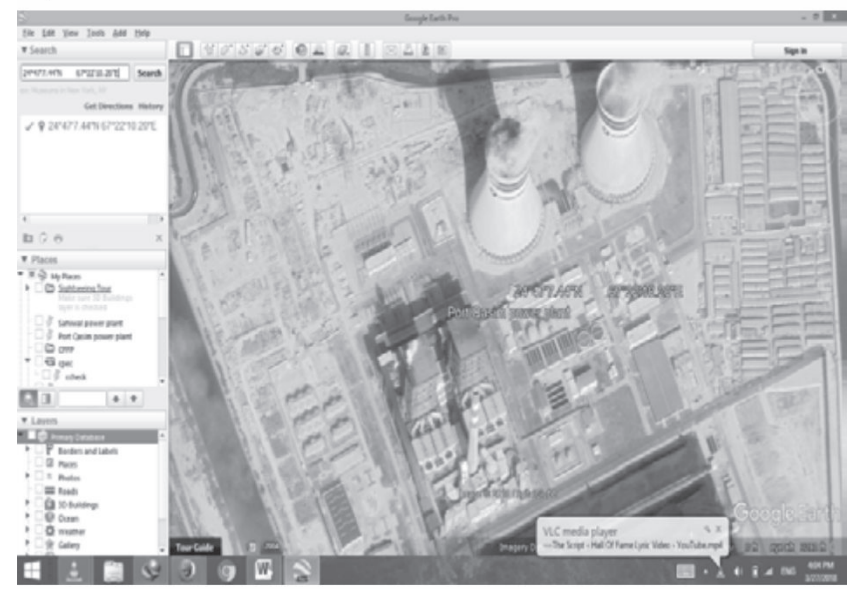

b)

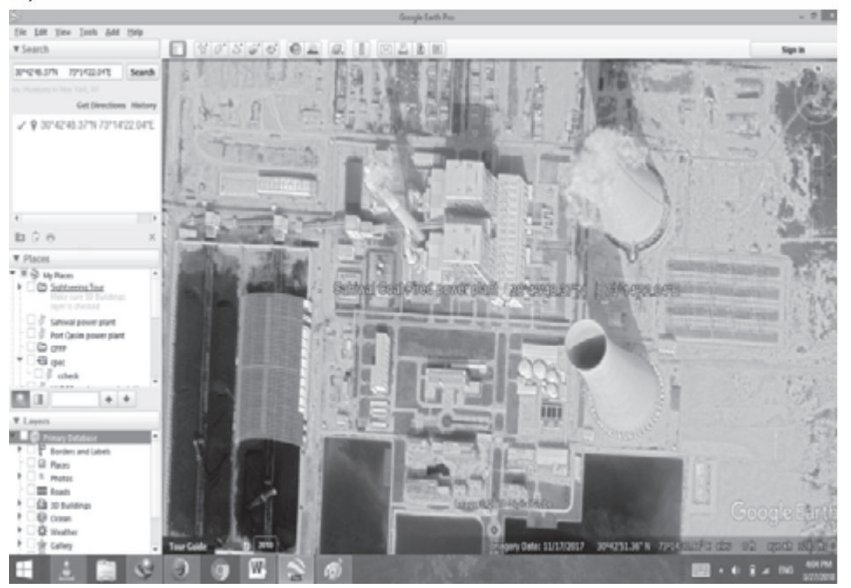

Fig. 3. Google Maps for a) Sahiwal Coal-Fired Power Plant, b) Port Qasim Coal-Fired Power Plant. Source: Author's own analysis

\section{Results and Discussion}

\section{Descriptive Analysis of Summer and Winter \\ Summer Concentration of Tropospheric Ozone in Pakistan (2010-2017)}

The spatial and temporal tropospheric ozone concentrations in summers are created through ArcMap from 2010 and 2017 and are illustrated in Fig. 6 and 2011-2016 (see Appendix). Overall analysis of the raster images showed that the highest concentrations are situated in the northern Punjab region and a small portion of KP. Northern Pakistan has comparatively the lowest concentration of tropospheric ozone. The raster map shows the distribution of tropospheric ozone concentrations in Pakistan, which shows variability across regions. To analyse this map, we look at the classification colours through the legend table, estimating the concentration in each region. The top beige colour represents the lowest concentration to be found in summers of 2010-2017. From the legend values analysis shows that with each passing year the highest ozone concentration level increases, and in some cases

Tropospheric Ozone Buffer Points Conc. Summer 2017

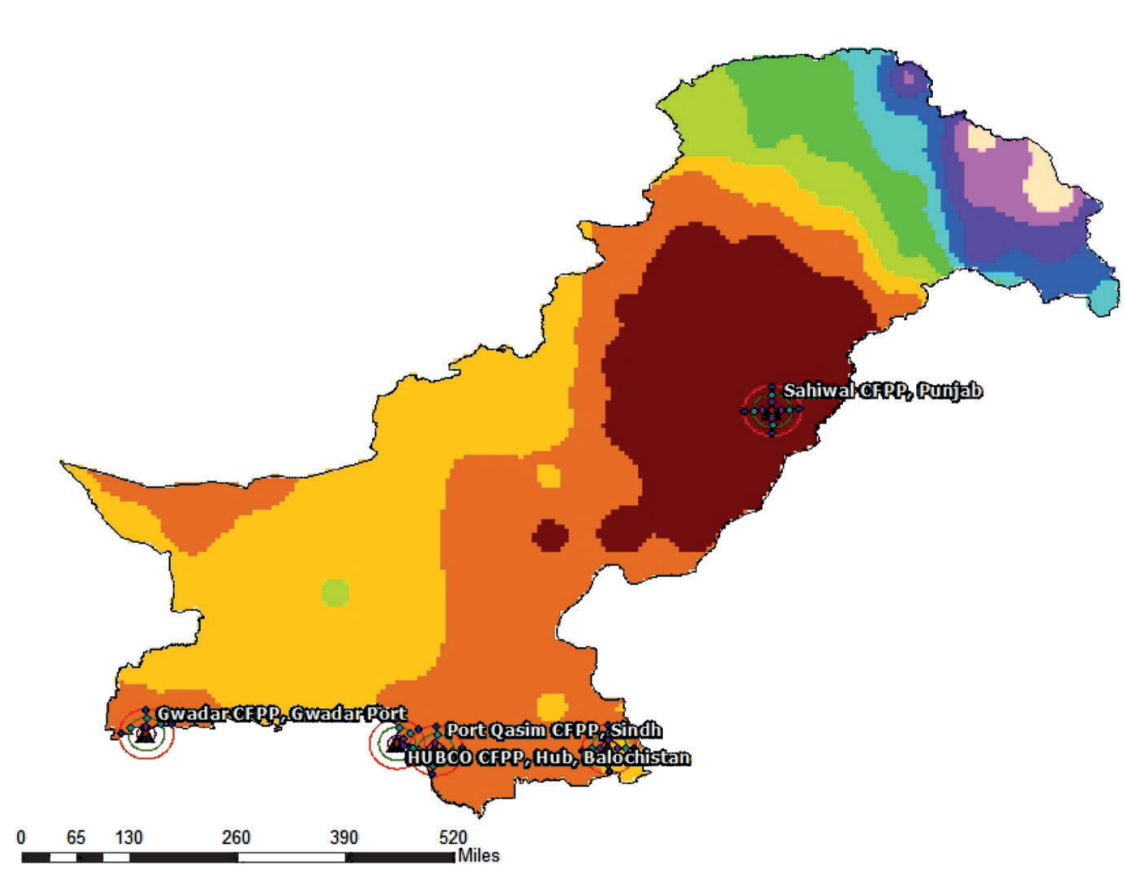

Legend

- Extract_Points1

- Extract_Buff_Po3

- Extract_Buff_Po2

- Extract_Buff_po1

- Shapefile_Buff_10M

- Buff_Shpfile_20M

- Point_Shapefile

Symbolld

$\Delta \quad 0$

Points_Buffer87

Points_Buffer86

$\square$ Points_Buffer85

rastersummer2017

<VALUE>

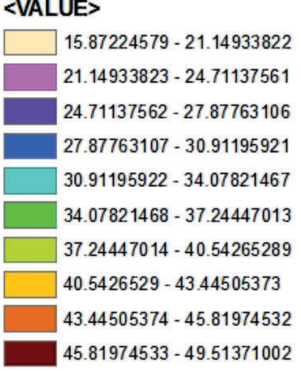

Fig. 4. Buffer zones and buffer points for summer and December 2017. Source: Author's analysis 
so does the brown highlighted region. The values of legend and its range are important to identify the changes in brown regions, merely the size variation does not depict the increase or decrease in concentrations.

From the raster images 2010-2017, the gradual increase in dark brown and light brown area has expanded from upper Punjab to Sindh and Baluchistan, with most change shown in the summer 2017 image as shown in Fig. 6, depicting all of Punjab with a high concentration of ozone ranging from 43.5 to $49.5 \mathrm{DU}$ and light brown areas covering KP, Sindh and some parts of Baluchistan ranging from 43.4 to 45.82 DU. All of Punjab, KP, Baluchistan, and Sindh have $\mathrm{TO}_{3}$ levels greater than $40.5 \mathrm{DU}$, which exceeds the standard level of $32.5 \mathrm{DU}$, according to WHO, EU, and UK guidelines. In comparison, the 2010 raster image has a dark brown area only in Upper Punjab with $\mathrm{TO}_{3}$ level ranging from 40.2 to $44.1 \mathrm{DU}$. There has been a $10.9 \%$ increase from 2010 to 2017 as shown in Fig. 6. Due to lower temperatures and low-pressure in northern areas such as the Himalayas and Karakorum range, the concentration of ozone is lower with a concentration of 27.90 DU to 34.20 with beige, pink and purple colours. This shows that the altitude difference and low-pressure in northern areas with higher wind speed leads to lower formation of $\mathrm{TO}_{3}$, hence more concentration levels in lower altitude with higher temperature areas as shown in Fig. 6.

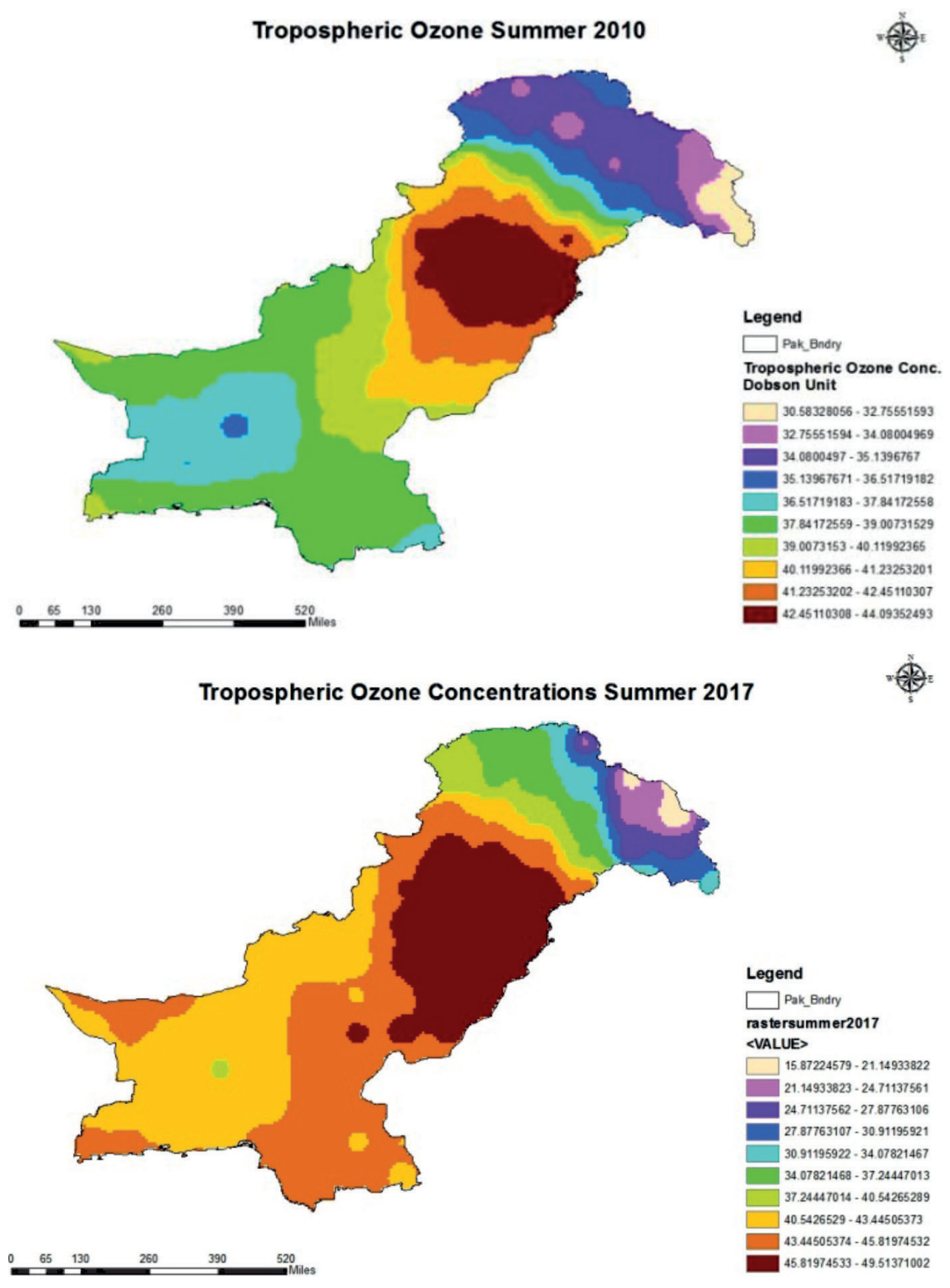

Fig. 6. Summer mean map of $\mathrm{TO}_{3}$ using OMI/MLS instruments from 2010 and 2017 (see Appendix Fig. I for more maps). 


\section{Winter Concentration of Tropospheric Ozone} in Pakistan (2010-2017)

The spatial and temporal tropospheric Ozone concentrations in summers are created through Arc Map from 2010-2017 and are illustrated in Fig. 7. The overall analysis of the raster images showed that winter has a relatively lower concentration of tropospheric ozone, which is concentrated in lower Baluchistan, Sindh and sometimes southern eastern Punjab, which could be explained by moderate temperatures in areas near the sea, relative to upper Punjab and northern areas. It is a natural phenomenon where regions near the ocean and sea have higher temperatures as compared to other northern regions. Now for 2010, even though most of Punjab and Sindh have dark brown areas, its $\mathrm{TO}_{3}$ levels are lower in the range 34.0 to $35.5 \mathrm{DU}$ as compared to the 2017 raster image as shown in Fig. 7, indicating 36.7 to 39.6 DU covering most of Punjab and Baluchistan and all of Sindh, with light brown and yellow regions between ranges 34.17 to $36.7 \mathrm{DU}$ and 31.4 to 34.1 DU respectively. For winters, the per year increase in tropospheric ozone levels is gradual, but a sharp increase has been seen in 2017 winters. Compared to 2016, there has been an increase in the maximum range by $7.16 \%$, which is a substantial change for one year as shown in Fig. 7.

\section{Tropospheric Ozone Winter 2010}

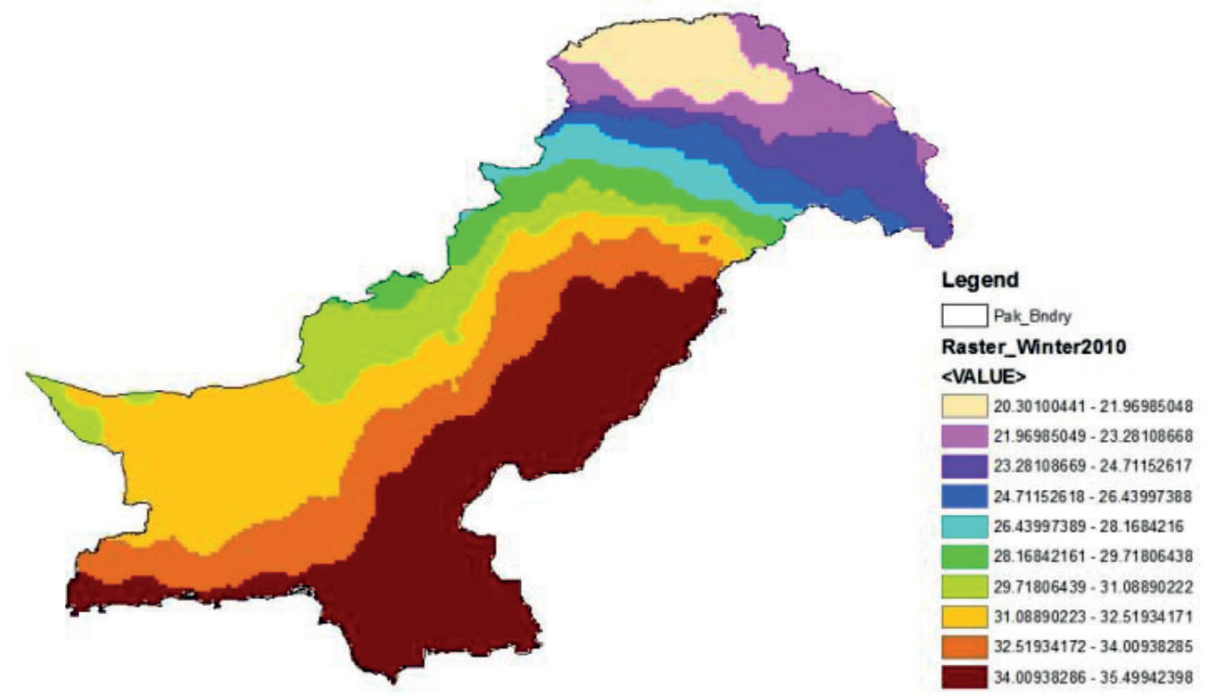

Tropospheric Ozone Concentrations Winter 2017

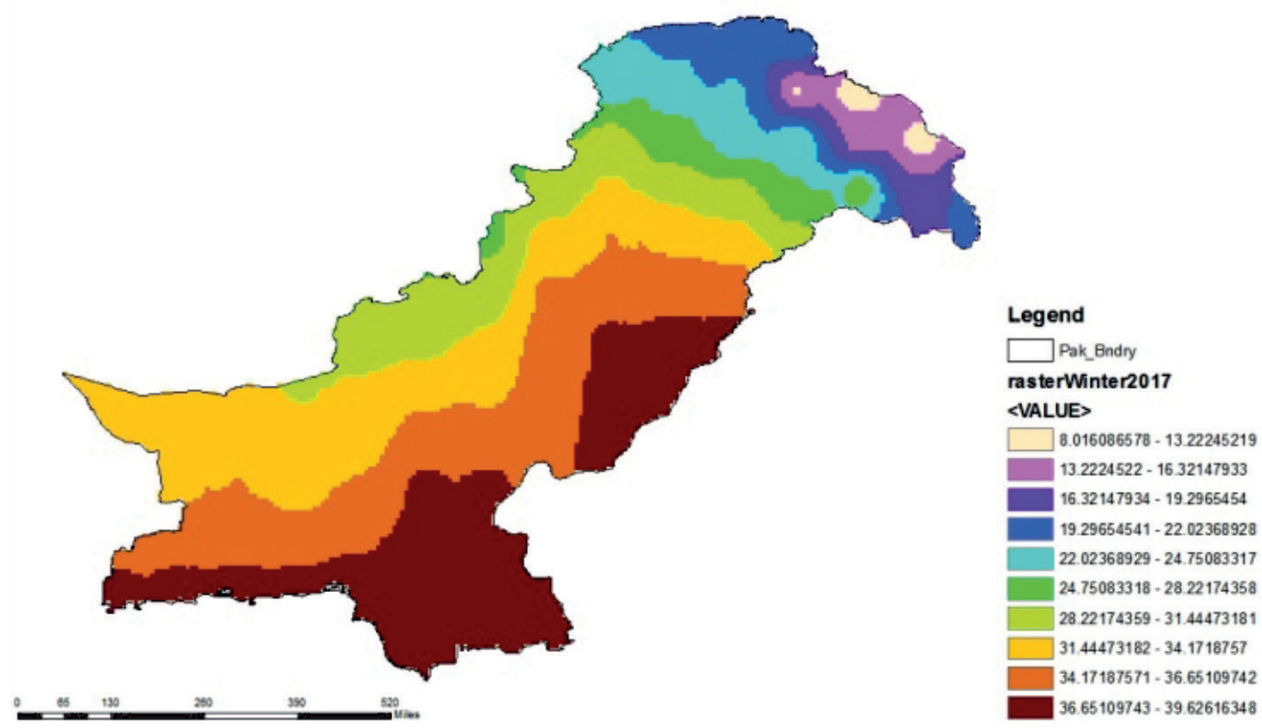

Fig. 7. Winter means map of $\mathrm{TO}_{3}$ using OMI/MLS instruments from 2010 and 2017 (see Appendix Fig. II). 
Table 1. Tropospheric ozone concentration at CFPP coordinates for 2010-2017 summers.

\begin{tabular}{|c|c|c|c|c|c|c|c|c|}
\hline & 2010 & 2011 & 2012 & 2013 & 2014 & 2015 & 2016 & 2017 \\
\hline Sahiwal CFPP, Punjab & 42.82 & 44.34 & 44.43 & 45.35 & 45.48 & 47.16 & 46.52 & 48.11 \\
\hline Port Qasim CFPP, Sindh & 38.60 & 39.25 & 40.28 & 41.48 & 41.89 & 44.00 & 41.82 & 44.77 \\
\hline
\end{tabular}

Source: Author's own analysis

Analysis of Sahiwal and Port Qasim CFPP $\mathrm{TO}_{3}$ Emissions for Summers and Winters

Pakistan is a developing country and requires energy resources to cater to the needs of development, urbanization and increasing population, hence the installation of coal-fired power plants under CPEC. Pakistan has extensive reserves of coal in Thar of around 185 billion tons [16], aimed at fueling 5 coal power plants providing $7000 \mathrm{MW}$ of energy by 2019-20 and 6\% annual growth in electricity production $[13,15]$. No doubt this will cover the supply deficit, but the environmental effects can be disastrous. To determine the possible effect a coal-fired power plant can have on changes in emissions - i.e., NOx and VOCs impacting $\mathrm{TO}_{3}$ and hence the ecosystem of Pakistan - this research estimated the formation of ozone in locations of new coal energy-based projects, looking at the $\mathrm{TO}_{3}$ levels in previous years without coalpower plant emissions, to obtain a trend and then see if there are any significant changes after 2015 in the concentration levels of $\mathrm{TO}_{3}$ at these locations in order to evaluate the impact as a result of CFPP construction and operation in that area.

In this study, the limitation remains on the effect of other anthropogenic factors on changes in emissions at the CFPP location, i.e., Sahiwal CFPP and Port Qasim CFPP such as geographical location, weather conditions, speed of photochemical reaction given favourable temperature and wind and the presence of $\mathrm{TO}_{3}$ precursors [46], which is not investigated in this research. However, future studies could be done to find the conditions and availability of primary pollutants at CFPP locations in order to get additional confirmation of the following results.

Table 1 shows Tropospheric Ozone concentration at the geographical locations where CFPPs were constructed after 2015 and to see the change each year before and after the power plants are constructed and operating. The Sahiwal CFPP was initiated in May 2015 and was operational in September 2017, whereas Port Qasim construction started in May 2015, with one unit in October 2017 and another unit in April 2018. Now for summers, since the CFPP was not yet operational in 2017, the $\mathrm{TO}_{3}$ formation is assumed to be higher than previous years (2010-2014), but as construction is going on and we cannot ignore the emissions of NOx and VOCs in the atmosphere of these locations, it may or may not have effect of $\mathrm{TO}_{3}$ formation far away from the source point. Since data was available through the
Aura satellite only until December 2017, this study can be continued for future impacts of power plants under CPEC.

The results in Table 1 and Fig. 8(a-b) show the concentrations of tropospheric ozone at both power plants from 2010-2017. From 2010-2014, there is a gradual increase in $\mathrm{TO}_{3}$ levels for both power plants ranging from 42.8 to 45.5 for Sahiwal CFPP and 36.6 to 41.9 for Port Qasim CFPP, but both have elevated concentrations in 2015 and 2017 with percentage increases of 3.55 and 4.81 in 2015 and 3.31 and 6.58 in 2017 (Table 2). There is a decrease in $2016 \mathrm{TO}_{3}$ concentration that has occurred due to unknown reasons, which can later be researched to evaluate the

\section{a) Sahiwal CFPP TO3 Concentrations}

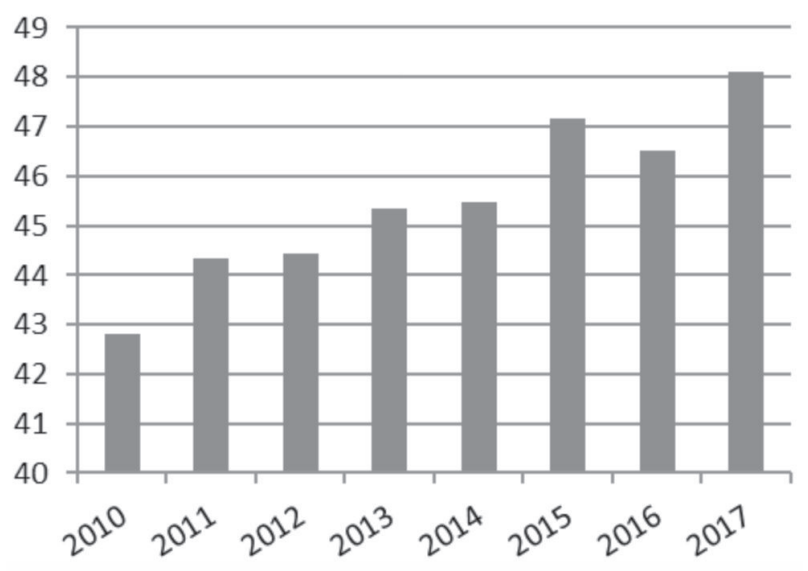

\section{b) Port Qasim CFPP TO3 concentrations}

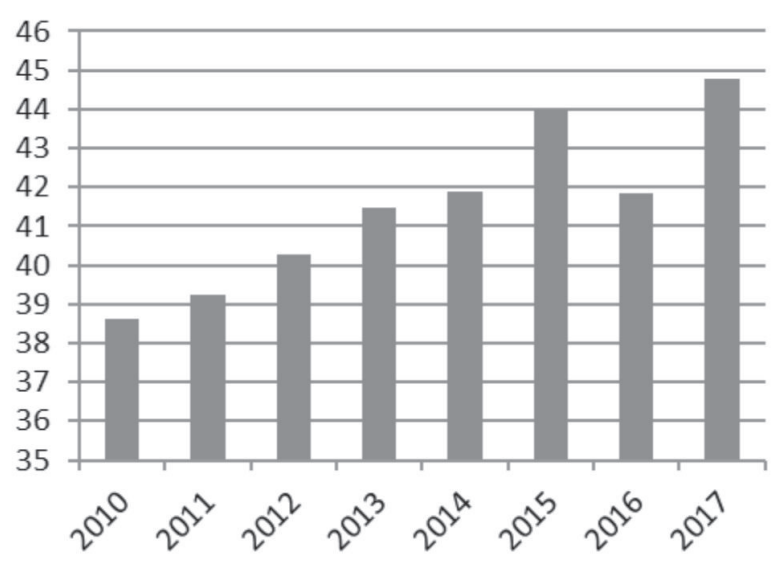

Fig. 8. Tropospheric ozone concentration at CFPP coordinates for 2010-2017 summers. 
Table 2. Percentage change in $\mathrm{TO}_{3}$ levels per year in 2010-2017 summers.

\begin{tabular}{|c|c|c|c|c|c|c|c|}
\hline & $\% \Delta$ & $\% \Delta$ & $\% \Delta$ & $\% \Delta$ & $\% \Delta$ & $\% \Delta$ & $\% \Delta$ \\
& $2010-2011$ & $2011-2012$ & $2012-2013$ & $2013-2014$ & $2014-2015$ & $2015-2016$ & $2016-2017$ \\
\hline Sahiwal CFPP, Punjab & 3.42 & 0.21 & 2.03 & 0.28 & 3.55 & -1.38 & 3.31 \\
\hline Port Qasim CFPP, Sindh & 1.66 & 2.55 & 2.89 & 0.98 & 4.81 & -5.21 & 6.58 \\
\hline
\end{tabular}

Source: Author's own analysis

a) 4

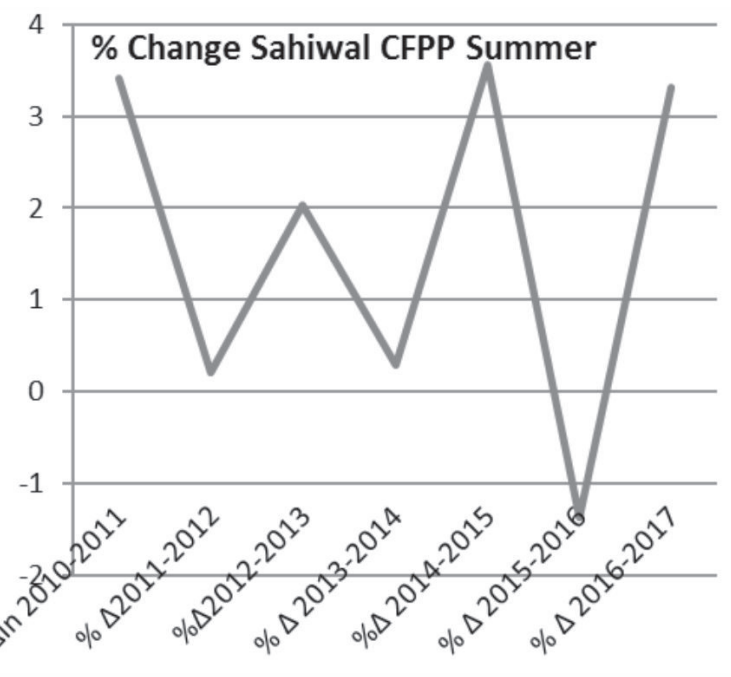

b) \% Change Port Qasim CFPP Summer

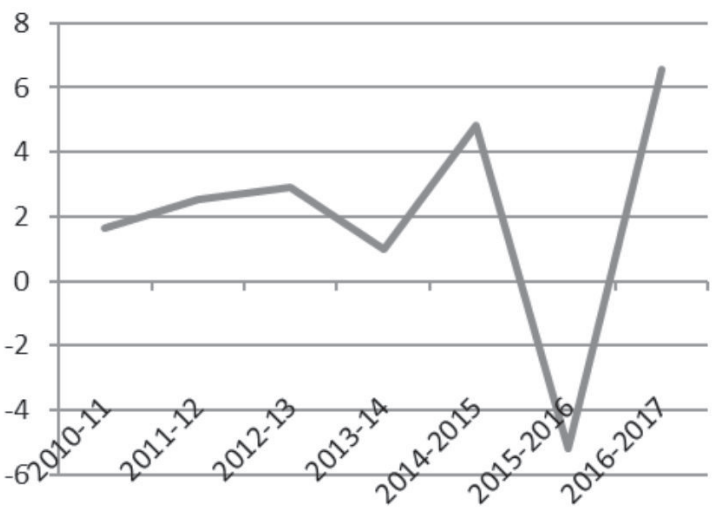

Fig. 9. Graphical representation percentage change in $\mathrm{TO}_{3}$ level per year in 2010-2017 summers.

anomaly. The percentage change can be represented by Fig. 9(a-b).

The results illustrated in Fig. 9 and Table 2 for summers does show a substantial impact of $\mathrm{TO}_{3}$ levels, which may not be because of direct emissions from a) Sahiwal CFPP emissions Winter

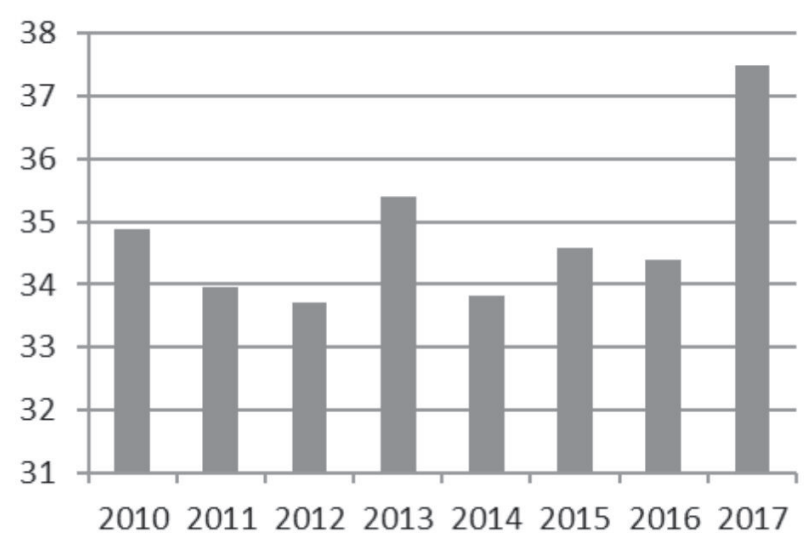

b)

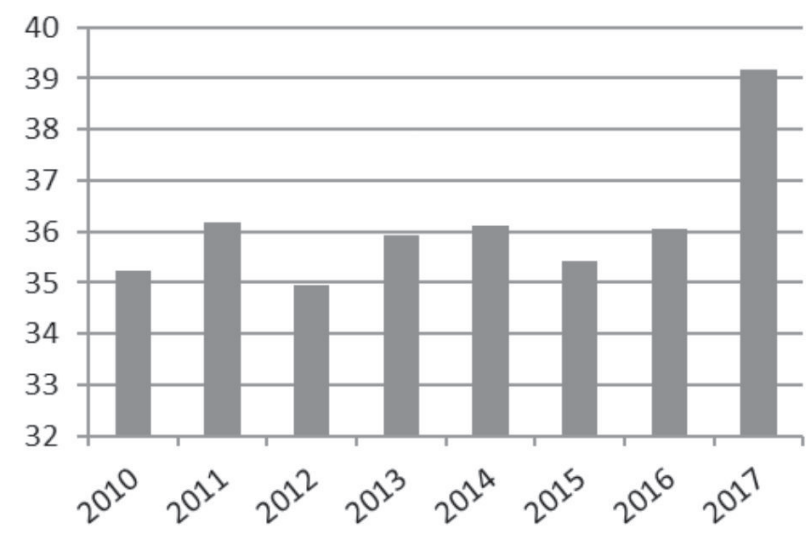

Fig. 10. Histogram showing $\mathrm{TO}_{3}$ at CFPP Coordinates for 2010-2017 summers.

source point but interpret the process of constructing CFPP, resulting in increased NOx and VOC emissions, hence changing $\mathrm{TO}_{3}$ levels.

In winters, the $\mathrm{TO}_{3}$ level is relatively lower throughout the years but shows a significant increase in 2017, pertaining to the fact that both CFPPs were

Table 3. Tropospheric ozone concentration at CFPP coordinates for winter from 2010-2017.

\begin{tabular}{|c|c|c|c|c|c|c|c|c|}
\hline & 2010 & 2011 & 2012 & 2013 & 2014 & 2015 & 2016 & 2017 \\
\hline Sahiwal CFPP, Punjab & 34.89 & 33.96 & 33.70 & 35.39 & 33.83 & 34.58 & 34.40 & 37.50 \\
\hline Port Qasim CFPP, Sindh & 35.25 & 36.18 & 34.94 & 35.93 & 36.12 & 35.42 & 36.05 & 39.16 \\
\hline
\end{tabular}


Table 4. Percentage change in $\mathrm{TO}_{3}$ level per year during 2010-2017 winters.

\begin{tabular}{|c|c|c|c|c|c|c|c|}
\hline & $\% \Delta$ & $\% \Delta$ & $\% \Delta$ & $\% \Delta$ & $\% \Delta$ & $\% \Delta$ & $\% \Delta$ \\
$2011-2011$ & $2011-2012$ & $012-2013$ & $13-2014$ & $2014-2015$ & $2015-2016$ & $2016-2017$ \\
\hline Sahiwal CFPP,Punjab & -2.75 & -0.76 & 4.78 & -4.61 & 2.15 & -0.51 & 8.28 \\
\hline Port Qasim CFPP, Sindh & 2.59 & -3.56 & 2.75 & 0.55 & -1.99 & 1.74 & 7.95 \\
\hline
\end{tabular}

operational in September and October 2017. The emissions from those power plants despite clean coal technology usage contributed to almost $8.28 \%$ for Sahiwal CFPP and $7.95 \%$ for Port Qasim increase in tropospheric ozone formation due to the presence of its precursors at those locations, as shown in Table 4 and Fig. 11(a-b). Even though in winters, ozone formation is low with a decrease and increase from years 2010-2016 at an average of 34.4 DU for Sahiwal CFPP and 35.7 DU. In 2017 as shown in Table 3 and Fig. 10(a-b), $\mathrm{TO}_{3}$ level in Port Qasim CFPP in 39.16 DU, which is greater than Sahiwal CFPP 37.50 DU because coastal areas in winters have a higher temperature than

a)

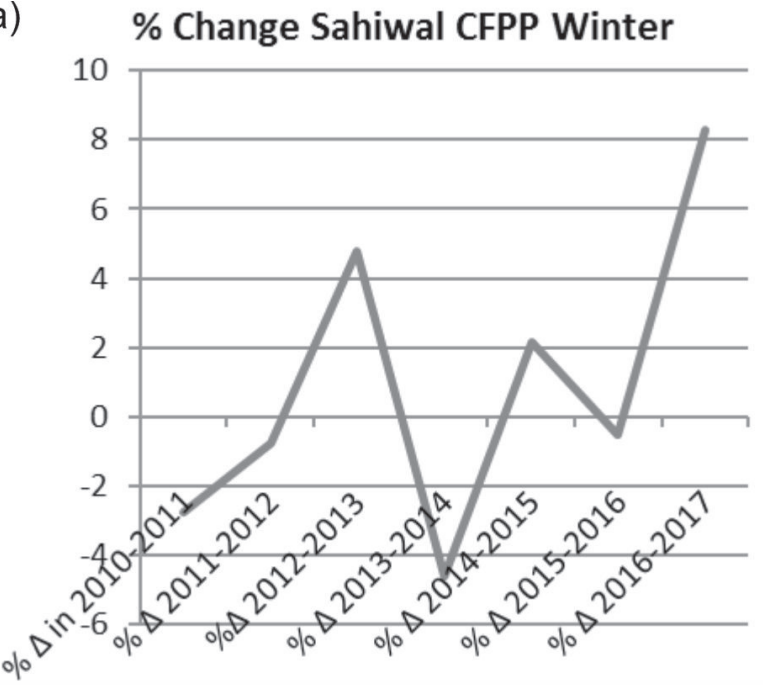

b) \% Change Port Qasim CFPP Winter

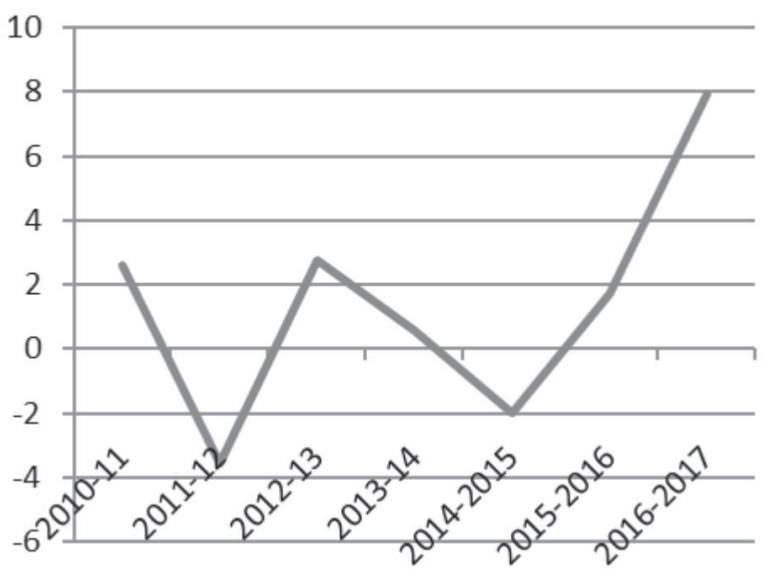

Fig. 11. Percentage change in $\mathrm{TO}_{3}$ levels per year in 2010-2017 summers. northern areas, giving preferable weather conditions at Port Qasim CFPP for ozone formation.

The hypothesis previously discussed:

$\mathrm{H} 0$ : There is no relationship between CFPPs of CPEC on tropospheric ozone concentrations.

H1: There is a significant relationship between CFPPs of CPEC on tropospheric ozone concentrations.

Based on the results from the satellite data, we reject $\mathrm{HO}$ and conclude that there is a significant relationship between tropospheric ozone levels in the atmosphere and CFPP emissions. This result aligns with the different studies from a literature review in which, with the installation of 1 unit a CFPP has almost a 10-times increase in NOx emissions in India [71], which has resulted in an increase of almost $8 \% \mathrm{TO}_{3}$ levels as shown in our study (Fig. 11). Annual changes of 8.11 $\mathrm{Tg}$ and $9.58 \mathrm{Tg}$ for Chinese coal plants shows 82\% correlation of its emissions with NOx emissions [61], and with $29.9 \%$ of VOCs, for which CFPPs account for [76], the probability of tropospheric ozone formation due to CFPPs is hence significant through our results.

Not much research has looked into finding the relationship between CFPP and tropospheric ozone in Pakistan, but a study from Candiota, Brazil studied tropospheric ozone impact due to CFPPs, and its findings showed results as significant, depicting to the reasons such as high temperature and low-intensity winds that help in accumulating the precursors of ozone and forming ozone. Our results showed 8.28\% for Sahiwal CFPP and 7.95\% Port Qasim CFPP increase in $\mathrm{TO}_{3}$ as they became operational, and the Port Qasim CFPP concentration is greater than Sahiwal CFPP emissions due to higher temperatures in coastal areas aligning with the result of Brazil and GLO of Chandrapur India, where CFPPs have a higher level of correlation with NOx and ozone formation with high temperature $(\mathrm{r}=0.55)$ and wind speed $[74,76]$. Our results are also endorsed by Verma [77], who found a significant relationship between CFPPs in India and $\mathrm{CO}_{2}, \mathrm{SO}_{2}$, and NOx formation, which also shows an increase in tropospheric ozone.

The results also ensure the concerns of environmentalist about air pollution [12, 90, 91] and refute the reassurances by Pakistani and Chinese governments and experts on the notion that CPEC will not create environmental problems and that Beijing will not transfer outdated technology to Pakistan's energy sector by installing superficial emission-reducing technology such as high thermal efficiency through high-efficiency electrostatic precipitator and flue gas desulfurization facilities that will reduce emissions 
[81, 92, 93]. Our results showed that emissions have increased substantially for the secondary pollutant, so the assumption is that primary pollutant emissions will be far greater (given that these readings are in winter when the temperature is comparatively lower than summertime in Pakistan). This raises the problem that if emissions of secondary pollutants are increasing to almost $8 \%$ just in the starting phase and in unfavorable weather conditions, what will be the state of air pollution and smog formation in Pakistan in the summer and future environmental impacts, hence answering the objective of study on CPEC energy projects as being environmentally friendly.

\section{Conclusions}

CPEC projects are receiving enormous attraction due to strategic location, economic intensification and vast resource mobilisation. At the heart, these projects provide an opportunity to curb the energy shortcomings through CFPPs, which have been planned to be developed with a net worth of $\$ 5.8$ billion US that is expected to supply $7000 \mathrm{MW}$ of electricity to national grid by 2019-2020, thus a $6 \%$ annual increase in electricity production in Pakistan. Simultaneously, environmentalists fear that these projects will increase GHG emissions, for which although they incorporate innovative and environmentally friendly technology (e.g., supercritical emission reducing technology), the uncertainties are enlarged. This study confirmed that the use of supercritical technologies like flue gas desulfurization, seawater desalination, and highefficiency electrostatic precipitators remains limited. This has certainly led to NOx emissions beyond the national environmental quality limits that have damaged the ozone layer over the two installed CFPPs in Sahiwal and Port Qasim. The results showed a significant mean change in concentration of tropospheric ozone for preCPEC and post-CPEC (i.e., after 2015) for summers at $2.29 \pm 1.27 \mathrm{DU}$ and for winters at $0.94 \pm 0.64 \mathrm{DU}$ in Pakistan. This shows that with more CPEC development projects underway, the emissions of primary pollutants such as NOX and VOCs will increase and affect the level of $\mathrm{TO}_{3}$ in the country. Here, the higher change in concentration of tropospheric ozone in summer is linked to a higher temperature during summertime in the study areas that pose more damage to ozone concentrations. This correlation of emissions (especially, NOx emissions) and $\mathrm{TO}_{3}$ at high temperature $(r=0.55)$ and wind speed is found to be significant in other parts of the world, such as Brazil and India [74, 76]. Further studies confirm more explicitly that a vital association exists between CFPPs and $\mathrm{CO}_{2}, \mathrm{SO}_{2}$, and NOx emissions that upset the tropospheric ozone [77], whereas from the CFPP perspective, this strong correlation is allied to evidence that the installation of 1 unit CFPP results in a 10-times increase in NOx emissions [71] and an annual change of $8.11 \mathrm{Tg}$ and
9.58 $\mathrm{Tg}$ in $\mathrm{TO}_{3}$ confirms an $82 \%$ increase in NOx and $29.9 \%$ increase in VOC emissions [72, 76]. Thus, a higher risk of changes in the tropospheric ozone formation due to emissions from three remaining CFPP signs high risk to local climate and inhabitants. The scenario therefore calls for effective use of critical technology in futuristic energy projects in order to avoid any anthropogenic hazards.

\section{Acknowledgments}

The authors of this study are thankful to this journal's Executive Editor Prof. Hanna Radecka and Editor in Chief Prof. Jerzy Radecki for pointing out the necessary structural changes and the initial review. Many thanks also to the anonymous reviewers for their thorough evaluation that refined this manuscript.

\section{Conflict of Interest}

The authors declare no conflict of interest.

\section{References}

1. TANG B.J., GONG P.Q., XIAO Y.C., WANG H. Y. Energy consumption flow and regional economic development: evidence from 25 economies. Journal of Modelling in Management, 12(1), 96, 2017.

2. RAZZAQI S., BILQUEES F., SHERBAZ S. Dynamic relationship between energy and economic growth: evidence from D8 countries. The Pakistan Development Review, 437, 2011.

3. RAZA H. China Pakistan Economic Corridor (CPEC): The counter balancer of momentous energy crisis in Pakitan. Advances in Social Sciences Research Journal, 5 (7), 2018

4. BOYCE, T. The China-Pakistan economic corridor: Trade securityand regional implications. Sandia Report. 2017.

5. MAKHDOOM A.S., SHAH A.B., SAMI K. Pakistan on the roadway to socio-economic development: A comprehensive study of China Pakistan Economic Corridor (CPEC). The Government-Annual Research Journal of Political Science., 6 (6), 2018.

6. HALI S.M., SHUKUI T., IQBAL S. One belt and one road: impact on China-Pakistan Economic Corridor. Strategic Studies, 34 (4), 147, 2015.

7. ABID M., ASHFAQ A. CPEC: Challenges and opportunities for Pakistan. Journal of Pakistan Vision, 16 (2), 142, 2015.

8. ANDREW S. CPEC: Road to the Future? Herald. 2016, November 15.

9. MUGHAL K. Energy sector projects under CPEC. Retrieved May, 15, 2017, 2016.

10. MARKEY D.S., WEST J. Behind China's gambit in Pakistan. Council on Foreign Relations, 5 (1), 2016.

11. AFZAL S., NASEEM A. China Pakistan Economic Corridor (CPEC): Challenges and Prospects. Pakistan Administrative Review, 2 (1), 209, 2018.

12. ADB. Basic 2018 statistics: Economic research and regional cooperation department, 2018. 
13. IMF. The Macroeconomics of Pakistan Quest for Energy and The CPEC: IMF Country Report. 2017. Islamabad: CPEC Center of Excellence

14. MOWP. National Power Policy. 2013. Ministry of Water and Power, Government of Pakistan.

15. HUSAIN I. CPEC and Pakistani economy: An appraisal. Islamabad: CPEC center of Excellence, 2018.

16. PLANNING COMMISSION. Vision 2030. In: Planning Commission of Pakistan (ed.). Pakistan: Government of Pakistan, 2007. Planning Commission: Government of Pakistan.

17. IEA. World Energy Outlook. France: International Energy Agency, 2010.

18. SHINDELL D., FALUVEGI G. The net climate impact of coal-fired power plant emissions. Atmospheric Chemistry and Physics, 3247, 2010.

19. CAI S.K. Research on Simultaneous Desulfurization and Denitrification by Combining Liquid-phase Oxidation with Limestone-gypsum System. Central South University, Changsha, China, 2012.

20. BRIMBLECOMBE P. Arie Jan Haagen-Smit and the history of smog. ECG Bulletin, 2012.

21. FIORE A.M., JACOB D.J., BEY I., YANTOSCA R.M., FIELD B.D., WILKINSON J.G. Background $\mathrm{O}_{3}$ over the united states in summer: origin, trend, and contribution to pollution episodes. Journal of Geophysical Research 107, 2002.

22. LOGAN J.A., STAEHELIN J., MEGRETSKAIA I.A., CAMMAS J.P., THOURET V., CLAUDE H., FRÖHLICH, M. Changes in ozone over Europe: Analysis of ozone measurements from sondes, regular aircraft (MOZAIC) and alpine surface sites. Journal of Geophysical Research: Atmospheres, 117 (D9), 2012.

23. PARRISH D.D., LAMARQUE J.F., NAIK V., HOROWITZ L., SHINDELL D.T., STAEHELIN J., GILGE S. Longterm changes in lower tropospheric baseline ozone concentrations: Comparing chemistry-climate models and observations at northern mid-latitudes. Journal of Geophysical Research: Atmospheres, 119 (9), 5719, 2014.

24. COOPER O.R., PARRISH D.D., ZIEMKE J., CUPEIRO M., GALBALLY I.E., GILGE S., OLTMANS S.J. Global distribution and trends of tropospheric ozone: An observation-based review, 2014.

25. ROYAL SOCIETY. Ground-level ozone in the 21st century: future trends, impacts and policy implications. Science Policy Report, 2008.

26. WHO. Air quality guidelines: global update 2005: particulate matter, ozone, nitrogen dioxide, and sulfur dioxide. World Health Organization, 2006.

27. HTAP. Hemispheric Transport of Air Pollution 2010. Part A.: Ozone and Particulate Matter Air Pollution Studies No. 17 United Nations, Geneva, Switzerland, 2010.

28. MONKS P.S., ARCHIBALD A.T., COLETTE A., COOPER O., COYLE M., DERWENT R., STEVENSON D.S. Tropospheric ozone and its precursors from the urban to the global scale from air quality to short-lived climate forcer. Atmospheric Chemistry and Physics, 15 (15), 2015.

29. USEPA. Integrated Science Assessment for Ozone and Related Photochemical Oxidants. EPA/600/R-10/076F Available: https://www.epa.gov/isa/integrated-scienceassessment-isa-ozone-and-related-photochemical-oxidants 2013, Accessed $31^{\text {st }}$ Dec 2018.

30. FUKS K.B., HÜLS A., SUGIRI D., ALTUG H., VIERKÖTTER A., ABRAMSON M.J., SCHIKOWSKI T. Tropospheric ozone and skin aging: Results from two
German cohort studies. Environment international, 124, 2019.

31. ALACCHI, G. Effect of Ozone on Cutaneous Tissues. In Textbook of Aging Skin (pp. 411-420). Springer, Berlin, Heidelberg, 2010.

32. KRUTMANN J., BOULOC A., SORE G., BERNARD B.A., PASSERON T. The skin aging exposome. Journal of dermatological science, 85 (3), 2017.

33. FUKS K.B., HÜLS A., SUGIRI D., ALTUG H., VIERKÖTTER A., ABRAMSON M.J., SCHIKOWSKI, T. Tropospheric ozone and skin aging: Results from two German cohort studies. Environment international, 124, 2019.

34. OECD. OECD Environmental Outlook to 2050. OECD Publishing, 2012.

35. STEVENSON D.S., DENTENER F.J., SCHULTZ M.G., ELLINGSEN K., VAN NOIJE T.P.C., WILD O., BERGMANN D.J. Multimodel ensemble simulations of present-day and near-future tropospheric ozone. Journal of Geophysical Research: Atmospheres, 111 (D8), 2006.

36. GREWE V. The origin of ozone. Atmospheric Chemistry and Physics, 6 (6), 1495, 2006.

37. BELAN B.D. Tropospheric ozone. 7. Sinks of ozone in troposphere. Opt. Atmos. Okeana, 23 (2), 108, 2010.

38. ANTOKHIN P.N., BELAN B.D. Control of the dynamics of tropospheric ozone through the stratosphere. Atmospheric and Oceanic Optics, 26 (3), 207, 2013.

39. BRÖNNIMANN S., NEU U. A possible photochemical link between stratospheric and near-surface ozone on Swiss mountain sites in late winter. Journal of atmospheric chemistry, 31 (3), 299, 1998.

40. BRÜHL C.H., CRUTZEN P.J. On the disproportionate role of tropospheric ozone as a filter against solar UV-B radiation. Geophysical Research Letters, 16 (7), 703, 1989.

41. BELAN B.D., IVLEV G.A., SKLYADNEVA T.K. Longterm monitoring of total and UV-B radiation in Tomsk. Atmospheric and Oceanic Optics, 25 (4), 281, 2012.

42. DANIELSEN E.F. Stratospheric-tropospheric exchange based on radioactivity, ozone and potential vorticity. Journal of the Atmospheric Sciences, 25 (3), 502, 1968.

43. KRZYSCIN J., KRIZAN P., JAROSŁAWSKI J. Longterm changes in the tropospheric column ozone from the ozone soundings over Europe. Atmospheric Environment, 41 (3), 606, 2007.

44. FOLLETTE-COOK M.B., HUDSON R.D., NEDOLUHA G.E. Classification of Northern Hemisphere stratospheric ozone and water vapor profiles by meteorological regime. Atmospheric Chemistry and Physics, 9 (16), 5989, 2009.

45. CRUTZEN P.J., LAWRENCE M.G., PÖSCHL U. On the background photochemistry of tropospheric ozone. Tellus B: Chemical and Physical Meteorology, 51 (1), 123, 1999.

46. MONKS P.S. A review of the observations and origins of the spring ozone maximum. Atmospheric Environment, 34 (21), 2000.

47. LOU S., LIAO H., YANG Y., MU Q. Simulation of the interannual variations of tropospheric ozone over China: Roles of variations in meteorological parameters and anthropogenic emissions. Atmospheric Environment, 2015.

48. GUENTHER A.B., JIANG X., HEALD C.L., SAKULYANONTVITTAYA T., DUHL T., EMMONS L.K., WANG X. The Model of Emissions of Gases and Aerosols from Nature version 2.1 (MEGAN2. 1): an extended and updated framework for modeling biogenic emissions, 2012. 
49. HUO H., YAO Z., ZHANG Y., SHEN X., ZHANG Q., DING Y., HE K. On-board measurements of emissions from light-duty gasoline vehicles in three mega-cities of China. Atmospheric Environment, 49, 371, 2012.

50. JAFFE D.A., WIGDER N.L. Ozone production from wildfires: A critical review. Atmospheric Environment, 51, $1,2012$.

51. POZZER A., ZIMMERMANN P., DOERING U. M., VAN AARDENNE J., TOST H., DENTENER F., LELIEVELD J. Effects of business-as-usual anthropogenic emissions on air quality. Atmospheric Chemistry and Physics, 12 (15), 6915, 2012

52. KUROKAWA J., OHARA T., MORIKAWA T., HANAYAMA S., JANSSENS-MAENHOUT G., FUKUI T., AKIMOTO $\mathrm{H}$. Emissions of air pollutants and greenhouse gases over Asian regions during 2000-2008: Regional Emission inventory in Asia (REAS) version 2. Atmospheric Chemistry and Physics, 13 (21), 11019, 2013.

53. MONKS P.S., ARCHIBALD A.T., COLETTE A., COOPER O., COYLE M., DERWENT R., STEVENSON D. S. Tropospheric ozone and its precursors from the urban to the global scale from air quality to short-lived climate forcer. Atmospheric Chemistry and Physics, 15 (15), 8889, 2015.

54. LOU S., LIAO H., YANG Y., MU Q. Simulation of the interannual variations of tropospheric ozone over China: Roles of variations in meteorological parameters and anthropogenic emissions. Atmospheric Environment, 2015.

55. DERWENT R.G., UTEMBE S.R., JENKIN M.E., SHALLCROSS D.E. Tropospheric ozone production regions and the intercontinental origins of surface ozone over Europe. Atmospheric Environment, 112, 216, 2005.

56. SAFIEDDINE S., BOYNARD A., HAO N., HUANG F., WANG L., JI D., CLERBAUX C. Tropospheric ozone variability during the East Asian summer monsoon as observed by satellite (IASI), aircraft (MOZAIC) and ground stations. Atmospheric Chemistry and Physics, 16 (16), 10489, 2016.

57. PARRISH D.D., LAMARQUE J.F., NAIK V., HOROWITZ L., SHINDELL D.T., STAEHELIN J., GILGE S. Longterm changes in lower tropospheric baseline ozone concentrations: Comparing chemistry-climate models and observations at northern mid-latitudes. Journal of Geophysical Research: Atmospheres, 119 (9), 5719, 2014.

58. VERSTRAETEN W.W., NEU J.L., WILLIAMS J.E., BOWMAN K.W., WORDEN J.R., BOERSMA K.F. Rapid increases in tropospheric ozone production and export from China. Nature geoscience, 8 (9), 690, 2015.

59. MONKS P.S. A review of the observations and origins of the spring ozone maximum. Atmospheric Environment, 34 (21), 2000.

60. NRC. Rethinking the ozone problem in urban and regional air pollution. National Academies Press, 1992.

61. MONKS P.S., ARCHIBALD A.T., COLETTE A., COOPER O., COYLE M., DERWENT R., STEVENSON D.S. Tropospheric ozone and its precursors from the urban to the global scale from air quality to short-lived climate forcer. Atmospheric Chemistry and Physics, 15 (15), 8889, 2015.

62. PUDASAINEE D., SAPKOTA B., SHRESTHA M. L., KAGA A., KONDO A., INOUE Y. Ground level ozone concentrations and its association with NOx and meteorological parameters in Kathmandu valley, Nepal. Atmospheric Environment, 40 (40), 8081, 2006.
63. NOREEN A., KHOKHAR M.F., ZEB,N., YASMIN N., HAKEEM, K. R. Spatio-temporal assessment and seasonal variation of tropospheric ozone in Pakistan during the last decade. Environmental Science and Pollution Research 25, 8441, 2018

64. JANA P.K., GOSWAMI S., MIDYA S.K. Relation between tropospheric and stratospheric ozone at Thumba $(8.5$ N, 77 E) and Bangalore (13 N, 77.5 E), India and its effect on environment. Indian Journal of Physics 86 (9), 769, 2012.

65. U.S.EPA. Air Pollutant Emissions Trends Data. 2014

66. SHI W.X., LIN C., CHEN W., HONG J.L., CHANG J.C., DONG Y., ZHANG Y.L. Environmental effect of current desulfurization technology on fly dust emission in China. Renew Sust Energ Rev 72, 1, 2017.

67. MOUSSIOPOULOS N. Influence of power plant emissions and industrial emissions on the leeward ozone levels. Atmospheric Environment. Part A. General Topics, 24 (6), 1451, 1990.

68. KUNHIKRISHNAN T., LAWRENCE M.G., VON KUHLMANN R., WENIG M.O., ASMAN W.A., RITCHER A. Regional NOx emission strength for the Indian subcontinent and the impact of emissions from India and neighboring countries on regional $\mathrm{O} 3$ chemistry. Journal of Geophysical Research 111, 2006.

69. XIONG T., JIANG W., GAO W. Current status and prediction of major atmospheric emissions from coal-fired power plants in Shandong Province, China. Atmospheric Environment 124, 46, 2016.

70. USC U.S.A. Coal and air pollution, 2017.

71. PRASAD A.K., SINGH R.P., KAFATOS M. Influence of coal-based thermal power plants on the spatialtemporal variability of tropospheric $\mathrm{NO}_{2}$ column over India. Environmental Monitoring Assessment 184, 1891, 2012.

72. WANG S.W., ZHANG Q., STREETS D.G., HE K.B., MARTIN R.V., LAMSAL L.N., ET AL. Growth in NOx emissions from power plants in China: bottomup estimates and satellite observations. Atmospheric Chemistry Physics 12, 4429, 2012.

73. UL HAQ Z., TARIQ S., ALI M., MAHMOOD K., BATOOL A., DAUD A. A study on $\mathrm{NO}_{2}$ variability over Pakistan using OMI data. Atmospheric pollution research. 5 (4), 2014

74. DALlAROSA J.B., TEIXEIRA E.C., ALVES R.C. Application of Numerical Models in the Formation of Ozone and its Precursors in Areas of Influence of CoalFired Power Station - Brazil. Water Air Soil Pollution, 385, 2007.

75. SILLMAN S. Ozone production efficiency and loss of NOx in power plant plumes: Photochemical model and interpretation of measurement in Tennessee. Journal of Geophysical Research 105, 9189, 2000.

76. SALVE P.R., SATAPATHY D.R., KATPATAL Y.B. WATE S.R. Assessing Spatial Occurrence of Ground Level Ozone around Coal Mining Areas of Chandrapur District, Maharashtra, India. Environment Monitoring Assessment, 87, 2007.

77. YAN Y., PENG L., LI R., LI Y., LI L., BAI H. Concentration, ozone formation potential and source analysis of volatile organic compounds (VOCs) in a thermal power station centralized area: A study in Shuozhou, China. Environmental Pollution 223, 295, 2017.

78. VARMA A.K., SRIMURALI M., MANJULA K.R Ozone Pollution in India Due to Power Plant Emissions. International Journal of Scientific Research, 2013. 
79. OLTMANSA S.J., LEFOHNB A.S., HARRISA J.M., GALBALLYD I., SCHEELE H.E., BODEKERF G., ET AL. Long-term changes in tropospheric ozone. Atmospheric Environment 40, 3156, 2006.

80. ZIEMKE J.R., CHANDRA S., LABOW G.J., BHARTIA P.K., FROIDEVAUX L., WITTE J.C. A global climatology of tropospheric and stratospheric ozone derived from Aura OMI and MLS measurements. Atmospheric Chemistry Physics, 9237, 2011.

81. IET. Chinese-backed Pakistani coal plants face fierce criticism due to environmental impact, 2017. Retrieved from The Institution of Engineering and Technology (IET): https://eandt.theiet.org/content/articles/2017/05/chinesebacked-pakistani-coal-plants-face-fierce-criticism-due-toenvironmental-impact/

82. LONSDALE C.R., STEVENS R.G., BROCK C.A., MAKAR P.A., KNIPPING E.M., PIERCE J.R. The effect of coal-fired power-plant $\mathrm{SO}_{2}$ and $\mathrm{NOx}$ control technologies on aerosol nucleation in the source plumes. Atmos. Chem. Phys, 2012.

83. POMYKAŁA R., MAZURKIEWICZ M. Properties of Coal Gasification Wastes Essential to Determining Their Impact on the Environment. Polish Journal of Environmental Studies, 24 (5), 2015.

84. VIEBAHN P., VALLENTIN D., HOLLER S. Prospects of carbon capture and storage (CCS) in China's power sector - An integrated assessment. Applied Energy 157, 229, 2015.

85. XU G., YANG Y.-P., LU S.-Y., LI L., SONG X. Comprehensive evaluation of coal-fired power plants based on grey relational analysis and analytic hierarchy process. Energy Policy 39, 2011.
86. MA Z., DENG J., LI Z., LI Q., ZHAO P., WANG L., ET AL. Characteristics of NOx emission from Chinese coal-fired power plants equipped with new technologies. Atmospheric Environment, 164, 2016.

87. ZIEMKE J.R., CHANDRA S., LABOW G.J., BHARTIA P.K., FROIDEVAUX L., WITTE J.C. A global climatology of tropospheric and stratospheric ozone derived from Aura OMI and MLS measurements. Atmospheric Chemistry Physics, 9237, 2011.

88. YE J.H., SHANG J., LI Q., XU W.W., LIU J., FENG $\mathrm{X}$., ZHU T. The use of vacuum ultraviolet irradiation to oxidize SO2 and NOx for simultaneous desulfurization and denitrification. J Hazard Mater 271, 89, 2014.

89. CHENG G., ZHANG C. Desulfurization and Denitrification Technologies of Coal-fired Flue Gas. Polish Journal of Environmental Studies, 27 (2), 2018.

90. IPCC. Working Group I: The Scientific Basis CH: 4; Atmospheric Chemistry and Greenhouse Gases. IPCC, 2001.

91. ICUN. Mainstreaming environment in the China-Pakistan Economic Corridor is must protect fragile environment of Pakistan, 2016. Retrieved from ICUN: https://www.iucn. org/news/pakistan/201612/mainstreaming-environmentchina-pakistan-economic-corridor-must-protect-fragileenvironment-pakistan

92. BALOCH S.M. CPEC's Environmental Toll. The Diplomat, 2018.

93. POWER CHINA. Sahiwal power plant- the first inaugurated CPEC project in Pakistan, 2017. Retrieved from Power China: Power Construction Corporation of China: http://en.powerchina.cn/2017-07/19/ content_30358906.html. 


\section{APPENDIX}

Summer concentrations of tropospheric ozone in Pakistan (2011-2016)

a)

Tropospheric Ozone Summer 2011

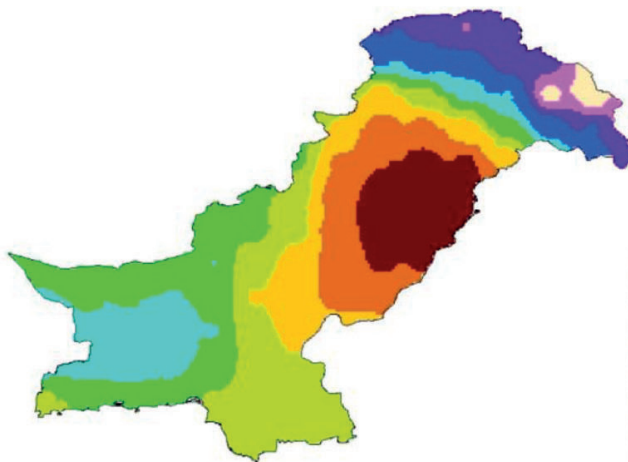

c)

Tropospheric Ozone Summer 2013 in Pakistan

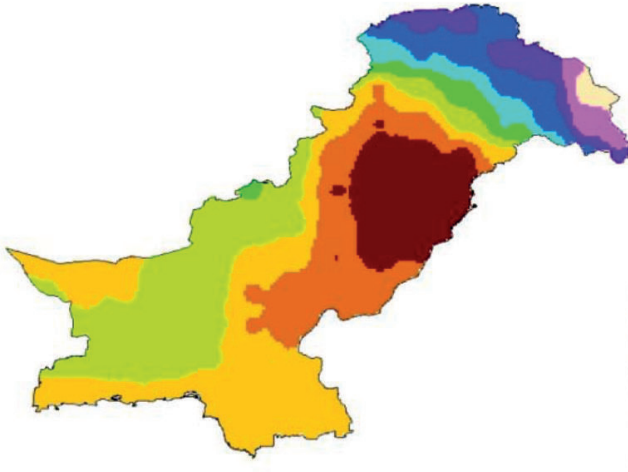

e)

Tropospheric Ozone Summer 2015 in Pakistan

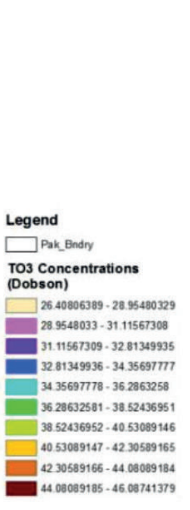

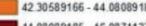

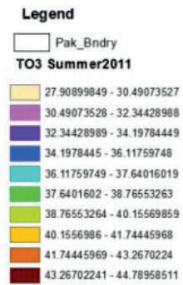

$41.74445969 \cdot-43.2670224$
$4326702241-4.7955951$
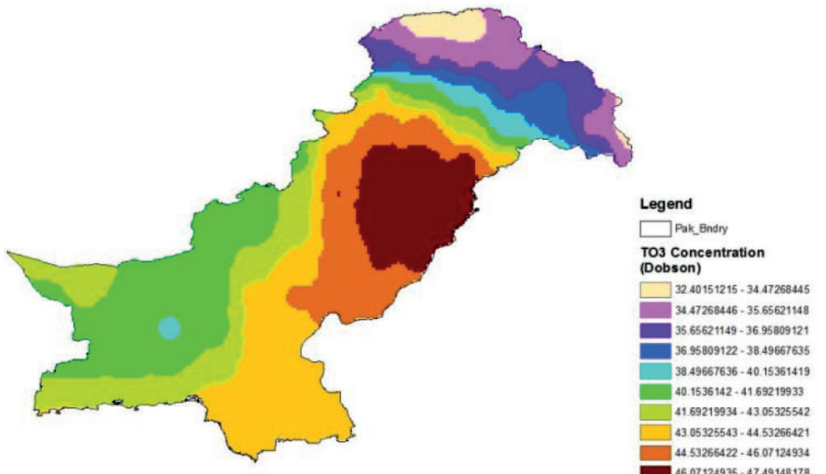

b)

Tropopsheric Ozone Summer 2012 in Pakistan

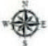

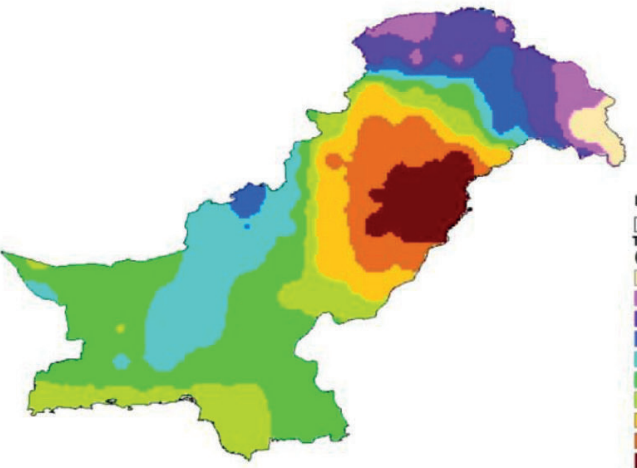

Legen

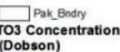

] $31.04161835-33723218$ $33.72321877-352316189$ 35

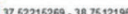
$4135121955-397000302$ 39.70095303-40.8741532 $40.87415321-4232666065$

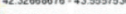

d)

Tropospheric Ozone Summer 2014 in Pakistan

雨,

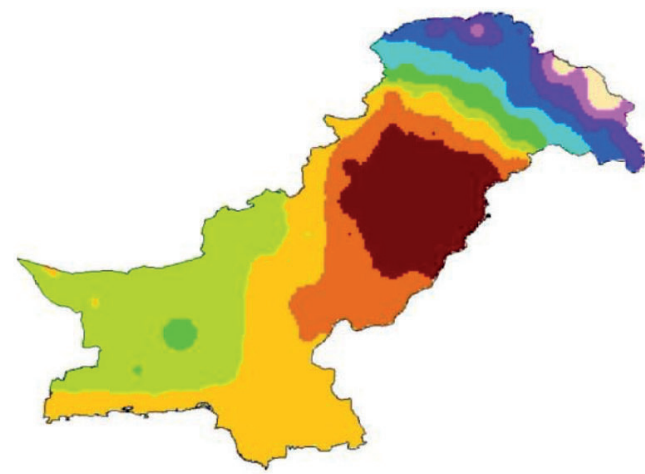

Legend $\longrightarrow$ Pak_Endry To3 Concentration
(Dobson) 25.61151695 2878929223 $2878929224-30.98929055$ $30.98929052-32.61891846$ $32.61891887-34.1670657$ $34.1670658-3636700406$

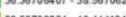
$40,4113995-4231520754$

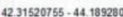
-

f)

Tropospheric Ozone Summer 2016 in Pakistan

- 雪。

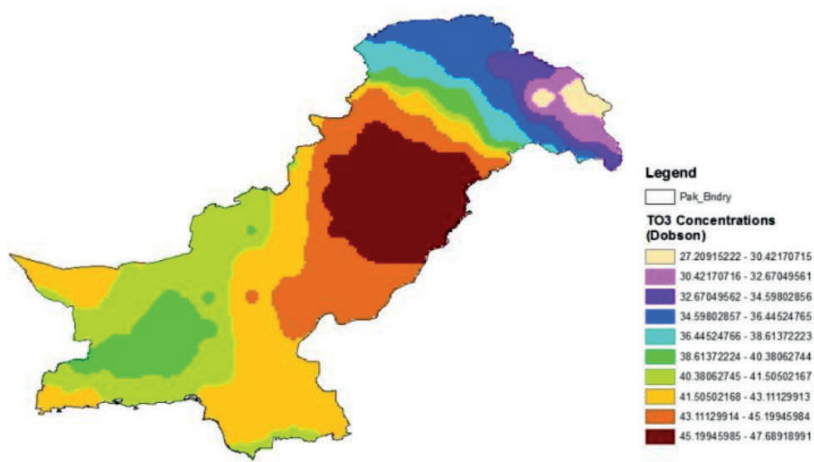

Fig. I. Summer mean map of TO3 using OMI/MLS instruments, 2011-2016. 
Winter concentrations of tropospheric ozone in Pakistan (2011-2016)

a)

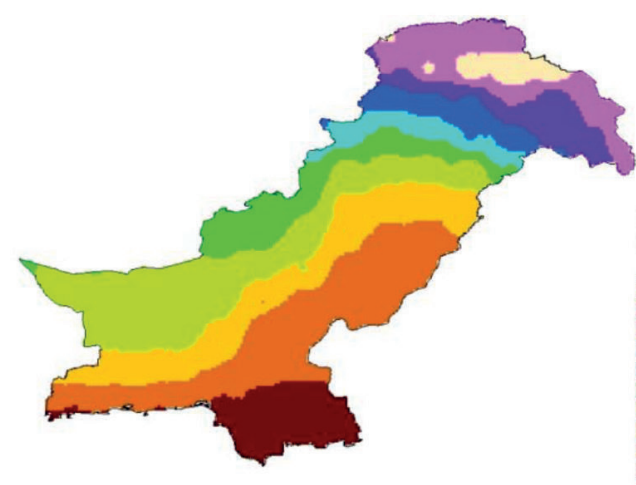

c)

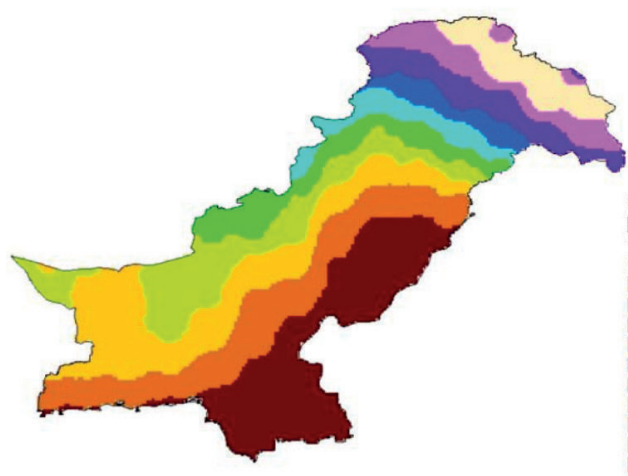

e)

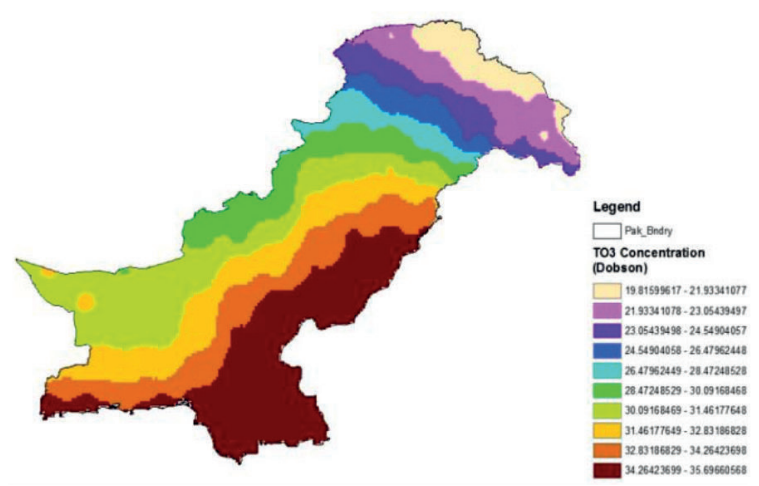

b)

Tropospheric Ozone Winter 2012 in Pakistan

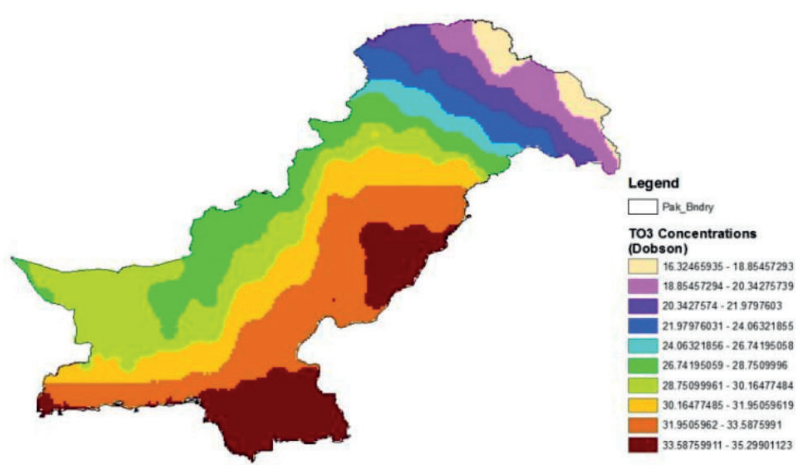

d)

Tropospheric Ozone Winter 2014 in Pakistan

雨

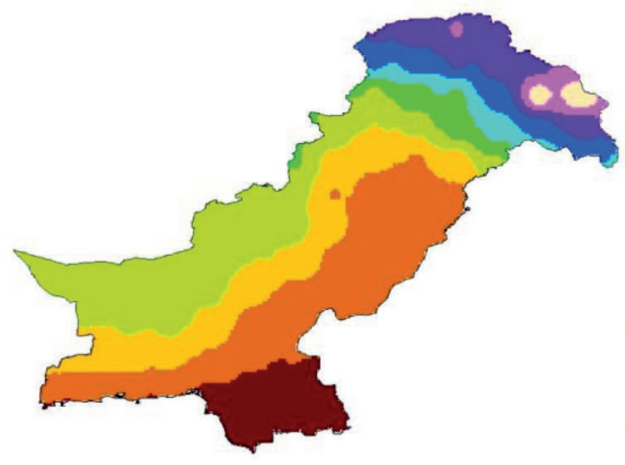

Legend

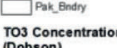

13.11237431-16.400293

$16.40082931-18.6597993$
$1865979931-207863129$

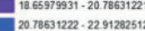

2291202513.25 50162345

$25.50162346 \cdot 28.182878696$

$324359047-345624176$

$32.67466785-34.47977415$

f)

Tropospheric Ozone Winter 2016 in Pakistan

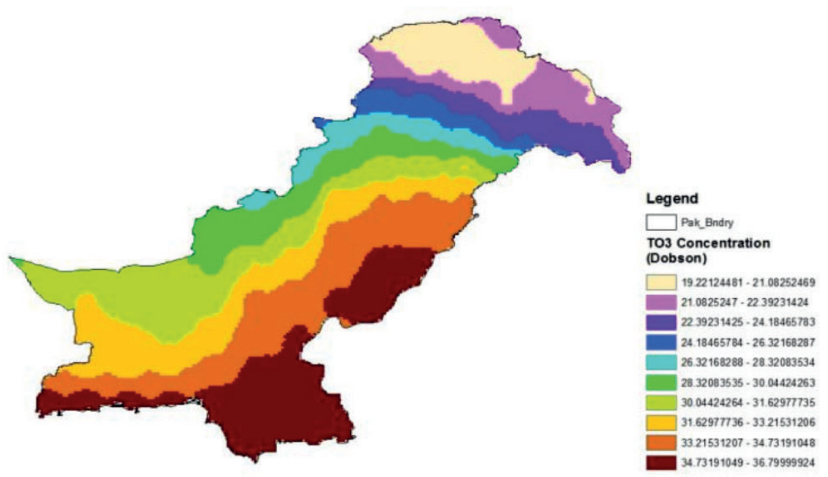

Fig. II. Winter means map of TO3 using OMI/MLS instruments, 2011-2016. 